\title{
Oak Ridge National Laboratory Office of International Nuclear Safeguards: Human Capital Development Activity in FY16
}

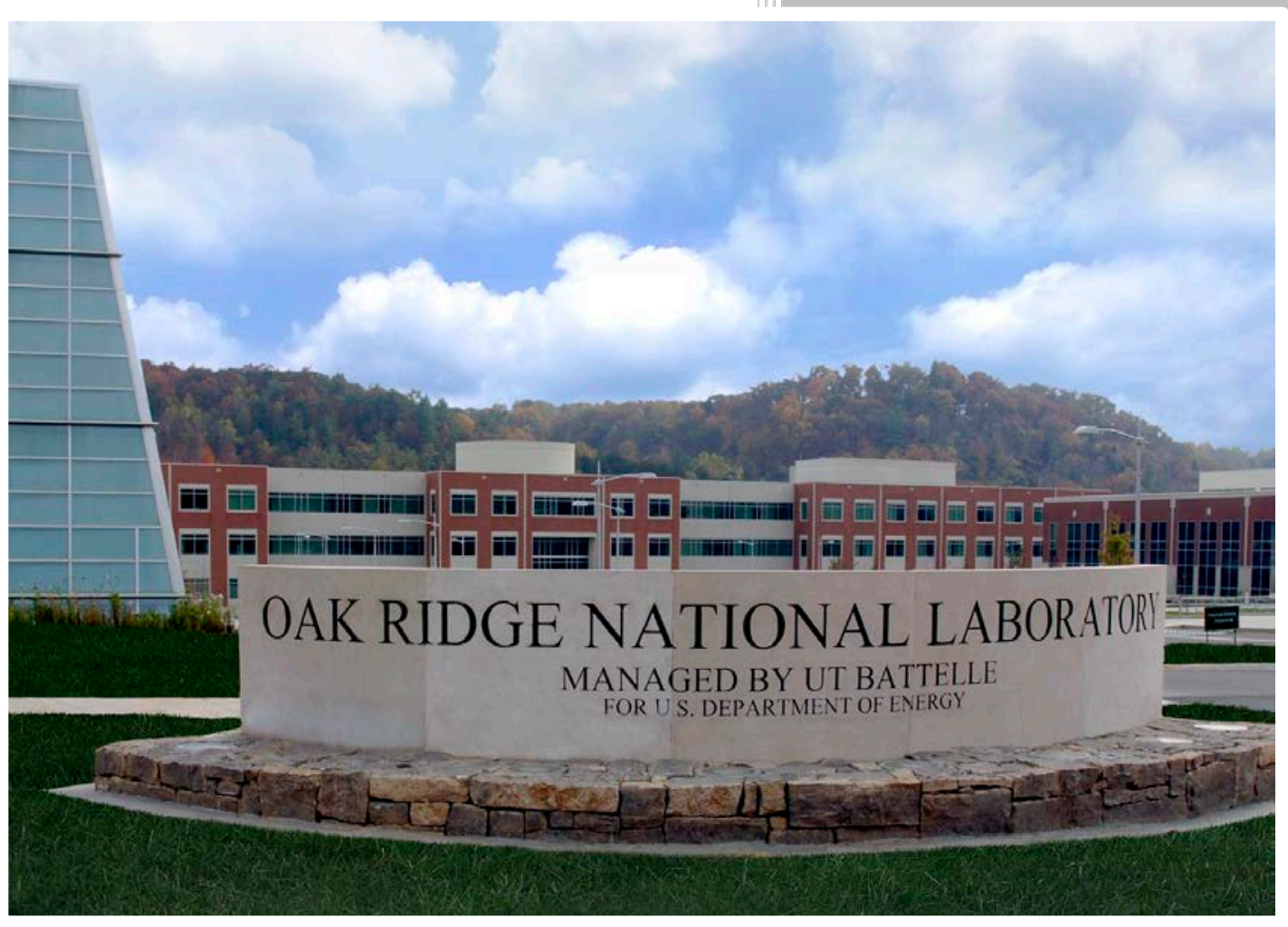

Approved for public release. Distribution is unlimited.
Kimberly V. Gilligan

Rachel N. Gaudet

September 2016 


\section{DOCUMENT AVAILABILITY}

Reports produced after January 1, 1996, are generally available free via US Department of Energy (DOE) SciTech Connect.

Website http://www.osti.gov/scitech/

Reports produced before January 1, 1996, may be purchased by members of the public from the following source:

National Technical Information Service

5285 Port Royal Road

Springfield, VA 22161

Telephone 703-605-6000 (1-800-553-6847)

TDD 703-487-4639

Fax 703-605-6900

E-mail info@ntis.gov

Website http://www.ntis.gov/help/ordermethods.aspx

Reports are available to DOE employees, DOE contractors, Energy Technology Data Exchange representatives, and International Nuclear Information System representatives from the following source:

Office of Scientific and Technical Information

PO Box 62

Oak Ridge, TN 37831

Telephone 865-576-8401

Fax 865-576-5728

E-mail reports@osti.gov

Website http://www.osti.gov/contact.html

This report was prepared as an account of work sponsored by an agency of the United States Government. Neither the United States Government nor any agency thereof, nor any of their employees, makes any warranty, express or implied, or assumes any legal liability or responsibility for the accuracy, completeness, or usefulness of any information, apparatus, product, or process disclosed, or represents that its use would not infringe privately owned rights. Reference herein to any specific commercial product, process, or service by trade name, trademark, manufacturer, or otherwise, does not necessarily constitute or imply its endorsement, recommendation, or favoring by the United States Government or any agency thereof. The views and opinions of authors expressed herein do not necessarily state or reflect those of the United States Government or any agency thereof. 
Nuclear Security and Isotope Technology Division

\title{
OAK RIDGE NATIONAL LABORATORY OFFICE OF INTERNATIONAL NUCLEAR SAFEGUARDS: HUMAN CAPITAL DEVELOPMENT ACTIVITY IN FY16
}

\author{
Kimberly V. Gilligan \\ Rachel N. Gaudet*
}

*Subcontractor through Oak Ridge Associated Universities (ORAU)

Date Published: September 2016

\author{
Prepared by \\ OAK RIDGE NATIONAL LABORATORY \\ Oak Ridge, Tennessee 37831-6283 \\ managed by \\ UT-BATTELLE, LLC \\ for the \\ US DEPARTMENT OF ENERGY \\ under contract DE-AC05-00OR22725
}





\section{CONTENTS}

Page

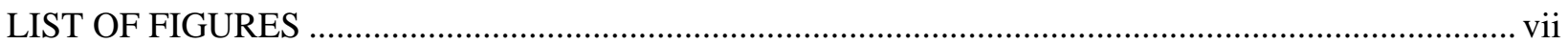

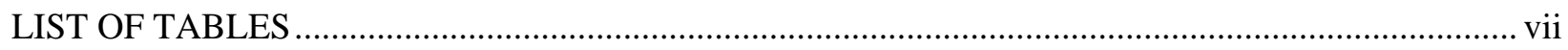

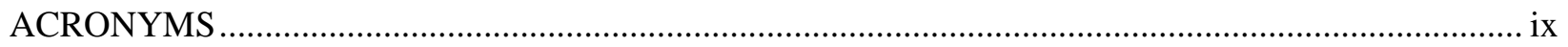

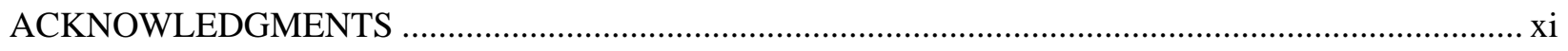

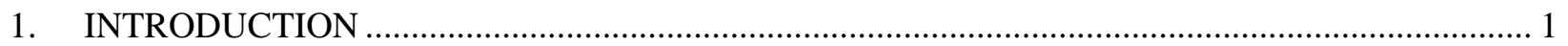

2. OINS SUPPORTED INTERNS AND GRADUATE ASSISTANTS AT ORNL ............................ 2

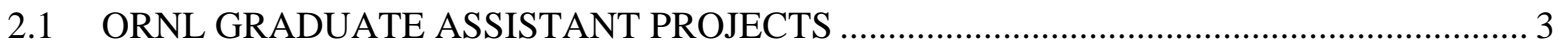

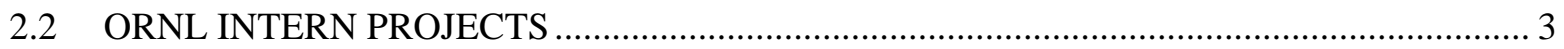

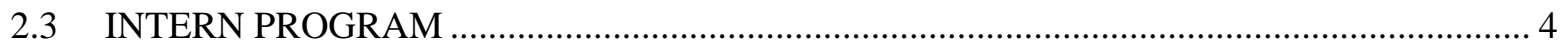

3. OINS SUPPORTED POSTGRADUATE APPOINTMENTS AT ORNL ….................................. 7

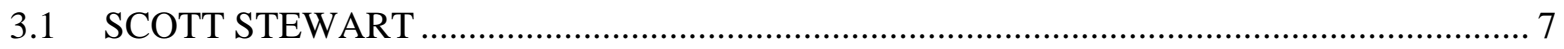

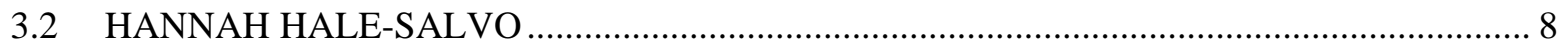

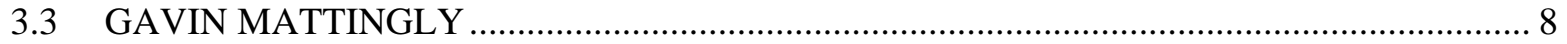

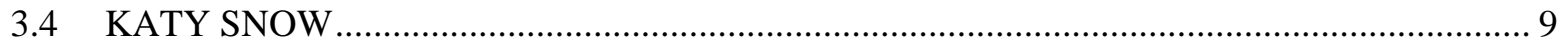

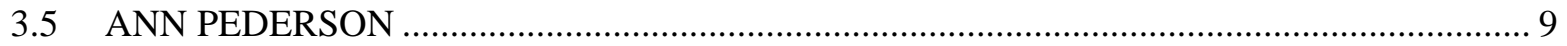

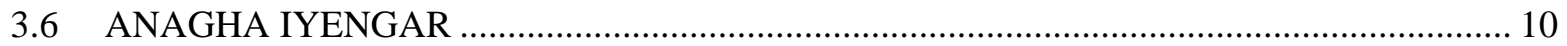

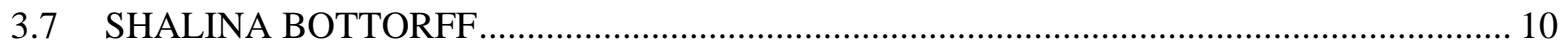

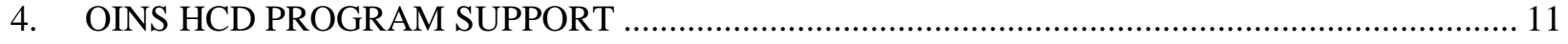

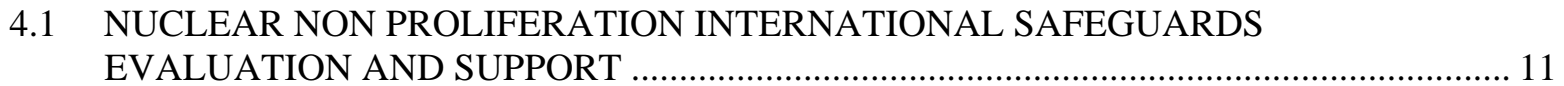

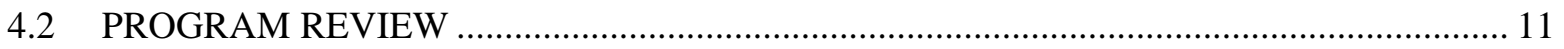

5. OINS UNIVERSITY ENGAGEMENT AND NONPROLIFERATION WORKSHOPS ................. 12

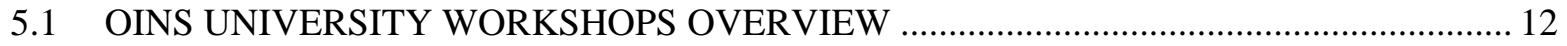

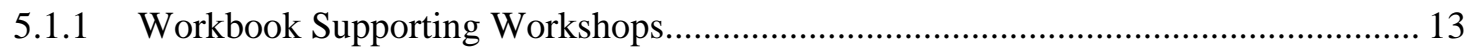

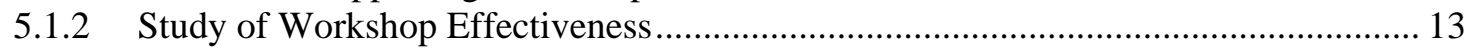

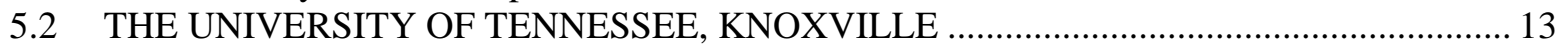

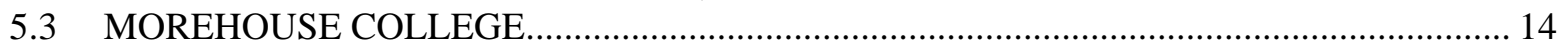

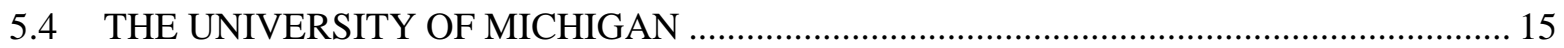

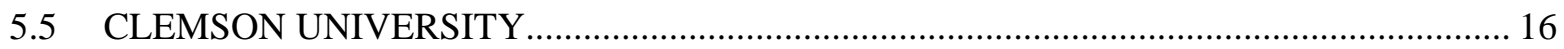

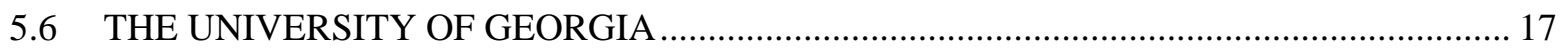

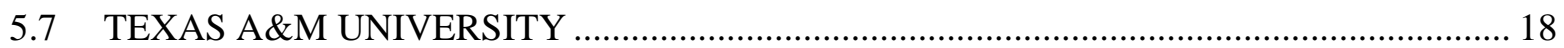

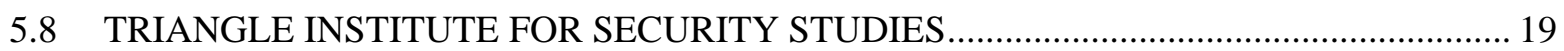

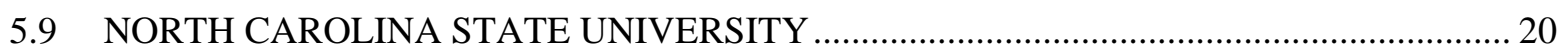

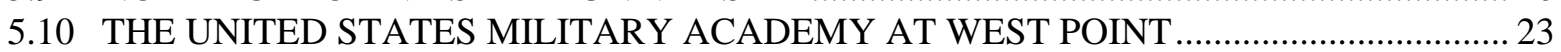

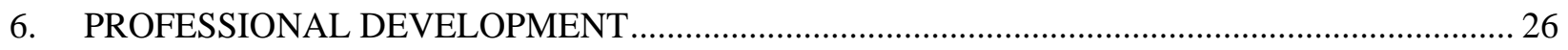

6.1 NEXT GENERATION SAFEGUARDS PROFESSIONAL NETWORK ACTIVITIES ........ 26

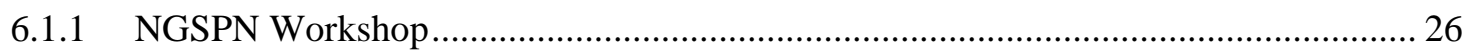

6.1.2 NonproliferationPortal.com ................................................................................ 26

7. STATEMENTS BY THOSE BENEFITING FROM OINS SUPPORTED HCD ACTIVTIES ......... 28

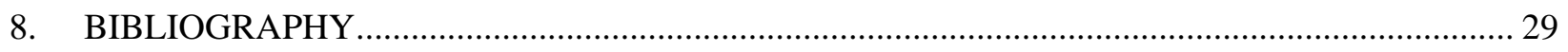





\section{LIST OF FIGURES}

Figure

Figure 1. Summer interns with mentors....................................................................................... 2

Figure 2. Chart indicating ORNL attendance at the OINS Summer Safeguards Lecture Series................. 5

Figure 3. Y-12's Jill Cooley presenting as part of the OINS Summer Safeguards Lecture Series

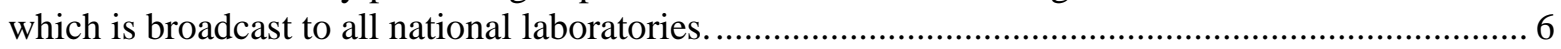

Figure 4. ORNL staff and students attending an OINS Summer Safeguards Lecture Series being

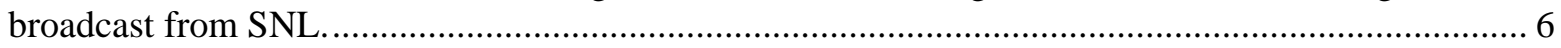

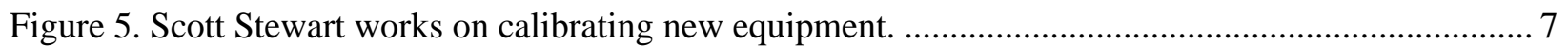

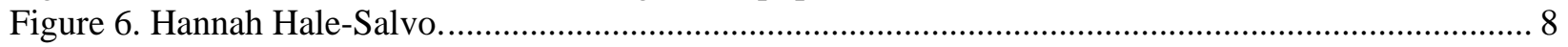

Figure 7. Research Associate Ann Pederson. ................................................................................... 9

Figure 8. ORNL staff Susan Smith (left) and Bob McElroy (second from right) with UTK nuclear

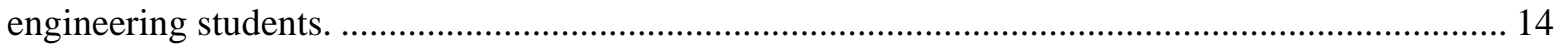

Figure 9. Morehouse College Students at ORNL for an OINS Nonproliferation Workshop. .................... 14

Figure 10. Alex Enders with the UM class at the portal monitor test bed............................................. 15

Figure 11. Andrew Nicholson assists UM with taking an NDA measurement........................................ 16

Figure 12. Clemson Students with Professor Timothy Devol and ORNL staff Greg Nutter and Steve

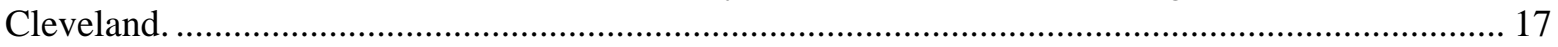

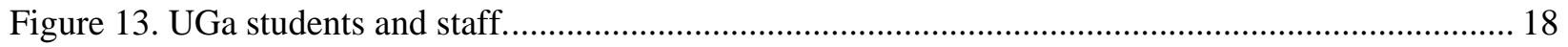

Figure 14. Ram Venkataraman and Greg Nutter stand with the Texas A\&M workshop participants........ 19

Figure 15. Chris Pickett speaking with TISS participants about IAEA seals. .......................................... 20

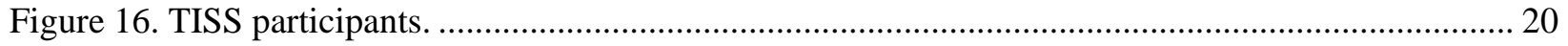

Figure 17. Steve Cleveland and Andrew Nicholson stand with the NCSU workshop participants............ 22

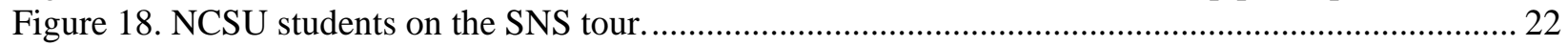

Figure 19. NCSU participants after enjoying Big Ed's Pizza in Oak Ridge. .......................................... 23

Figure 20. West Point Faculty and Cadets with ORNL's Ram Venkataraman......................................... 24

Figure 21. West Point cadet taking an NDA measurement in the Safeguards Laboratory........................ 25

Figure 22. Gavin Mattingly and Steve Cleveland at the NGSPN Meeting at BNL................................ 26

Figure 23. NDA Topic on NonproliferationPortal.com......................................................................... 27

Table

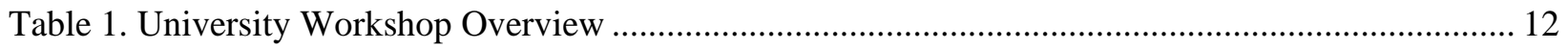




\section{ACRONYMS}

$\begin{array}{ll}\text { ANL } & \text { Argonne National Laboratory } \\ \text { AWCC } & \text { active well coincidence counter } \\ \text { BNL } & \text { Brookhaven National Laboratory } \\ \text { CTBTO } & \text { Comprehensive Nuclear-Test-Ban Treaty Organization } \\ \text { DOE } & \text { US Department of Energy } \\ \text { FY } & \text { fiscal year } \\ \text { HCD } & \text { human capital development } \\ \text { HFIR } & \text { High Flux Isotope Reactor } \\ \text { IAEA } & \text { International Atomic Energy Agency } \\ \text { INL } & \text { Idaho National Laboratory } \\ \text { INSEP } & \text { International Nuclear Safeguards Engagement Program } \\ \text { ISOCS } & \text { in situ object characterization } \\ \text { LANL } & \text { Los Alamos National Laboratory } \\ \text { LLNL } & \text { Lawrence Livermore National Laboratory } \\ \text { NCSU } & \text { North Carolina State University } \\ \text { NDA } & \text { nondestructive analysis } \\ \text { NESLS } & \text { Nuclear Engineering Science Laboratory Synthesis } \\ \text { NGSI } & \text { Next Generation Safeguards Initiative } \\ \text { NGSPN } & \text { Next Generation Safeguards Professional Network } \\ \text { NNIS } & \text { Nuclear Nonproliferation International Safeguards } \\ \text { NNSA } & \text { National Nuclear Security Administration } \\ \text { NPAC } & \text { NNSA Office of Nonproliferation and Arms Control } \\ \text { OINS } & \text { Office of International Nuclear Safeguards } \\ \text { ORAU } & \text { Oak Ridge Associated Universities } \\ \text { ORNL } & \text { Oak Ridge National Laboratory } \\ \text { PNNL } & \text { Pacific Northwest National Laboratory } \\ \text { REDC } & \text { Radiochemical Engineering Development Center } \\ \text { SGS } & \text { Segmented Gamma Scanner } \\ \text { SNL } & \text { Sandia National Laboratories } \\ \text { SNM } & \text { special nuclear material } \\ \text { SNS } & \text { Spallation Neutron Source } \\ \text { TISS } & \text { Triangle Institute for Security Studies } \\ \text { UM } & \text { University of Michigan } \\ \text { UTK } & \text { University of Tennessee, Knoxville } \\ \text { Y-12 } & \text { Y-12 National Security Complex } \\ & \end{array}$





\section{ACKNOWLEDGMENTS}

The authors wish to thank the U.S. Department of Energy's National Nuclear Security Administration Office of Nonproliferation and Arms Control (NPAC) for its support of the Human Capital Development projects since fiscal year 2009, particularly staff members Dunbar Lockwood, Melissa Einwechter, Kate Glynn, and Wayne Mei, for their encouragement and approval to continue the programs. Thanks are also extended to Oak Ridge National Laboratory (ORNL) Associate Laboratory Director Alan Icenhour for his enthusiasm and support of university outreach.

The university Next Generation Safeguards Initiative nonproliferation workshops held at ORNL are successful because of the willingness of staff members to mentor the students. Although this effort takes many dedicated people, special thanks are extended to the Safeguards and Security Technology Group, George Flanagan, Fred Peretz, Michael Whitaker, Porter Bailey, and the High Flux Isotope Reactor staff. The summer internship program is made possible by the efforts of Amy Hunt and Diana Tucker. Diana Tucker was also the key person in working with North Carolina State University to incorporate ORNL experts into the curriculum. Bernie Kirk worked with the universities to evaluate the workshops and make recommendations to strengthen the experience for students. Finally, Ray Smith and Jill Cooley of the Y-12 National Security Complex extended valuable opportunities to our university partners.

The continued success of the education outreach is also dependent on the following individuals who serve on the 2016 Nuclear Science and Engineering Directorate Education Outreach Committee. These individuals have donated hours of work to ensure the success of the program, particularly Julie Ezold, Adam Aaron, and Barbara Snow. 



\section{INTRODUCTION}

In 2007, the U.S. Department of Energy National Nuclear Security Administration (DOE NNSA) Office of Nonproliferation and Arms Control (NPAC) completed a comprehensive review of the current and potential future challenges facing the international safeguards system. The review examined

- trends and events that have an effect on the mission of international safeguards,

- the implications of expanding and evolving mission requirements of the legal authorities and institutions that serve as the foundation of the international safeguards system, and

- the technological, financial, and human resources required for effective safeguards implementation.

The review's findings and recommendations were summarized in the report International Safeguards: Challenges and Opportunities for the 21st Century (NNSA, 2007). The executive summary of this report is available at http://nnsa.energy.gov/sites/default/files/nnsa/inlinefiles/NGSI_Report.pdf.

One of the report's key recommendations was for DOE NNSA to launch a major new program to revitalize the international safeguards technology and human resource base. In 2007, at the International Atomic Energy Agency (IAEA) General Conference, then Secretary of Energy Samuel W. Bodman announced the newly created Next Generation Safeguards Initiative (NGSI). NGSI consists of five program elements:

- policy development and outreach,

- concepts and approaches,

- technology and analytical methodologies,

- human capital development (HCD), and

- infrastructure development.

This report addresses the HCD component of NGSI. The goal of the HCD component as defined in the NNSA Program Plan is "to revitalize and expand the international safeguards human capital base by attracting and training a new generation of talent.” The major objectives listed in the HCD goal include education and training, outreach to universities and professional societies, postdoctoral appointments, and summer internships at national laboratories.

Oak Ridge National Laboratory (ORNL) is a participant in the NGSI program, together with several other DOE laboratories, such as Pacific Northwest National Laboratory (PNNL), Lawrence Livermore National Laboratory (LLNL), Brookhaven National Laboratory (BNL), and Los Alamos National Laboratory (LANL). ORNL's participation specifically encompasses student internships, postgraduate appointments, collaboration with universities in safeguards curriculum development, workshops, and outreach.

The HCD program is now funded through the Office of International Nuclear Safeguards (OINS) (which previously managed the NGSI). The HCD program remains committed to supporting the next generation of safeguards professionals through academic and professional development opportunities, outreach, and interactive workshops. 


\section{OINS SUPPORTED INTERNS AND GRADUATE ASSISTANTS AT ORNL}

ORNL OINS HCD hosted five interns and three graduate assistants in FY 2016, mostly during the summertime. Many ORNL interns come under the Nuclear Engineering Science Laboratory Synthesis (NESLS) internship program, which is geared toward students in scientific disciplines who have an interest in nuclear science and engineering. Internships are typically full time for 10 weeks in the summer. Some interns are then invited to stay on during the school year.

The student breakdown included:

- Rachel Gaudet, intern and a May 2016 graduate in nuclear engineering at the University of Tennessee, Knoxville (UTK), about to begin a Ph.D. program in nuclear engineering at UTK;

- Alexandra Hackett, graduate assistant in nuclear engineering at UTK;

- Chris Andrews, graduate assistant in nuclear engineering at UTK;

- Angela Simone, intern and graduate assistant in nuclear engineering at UTK;

- Joseph Cope, intern and bachelor's student in nuclear engineering at North Carolina State University (NCSU);

- Adam Drescher, intern and master's student in nuclear engineering at University of Texas, Austin; and

- Scott Richards, intern and Ph.D. student in nuclear engineering at UTK.

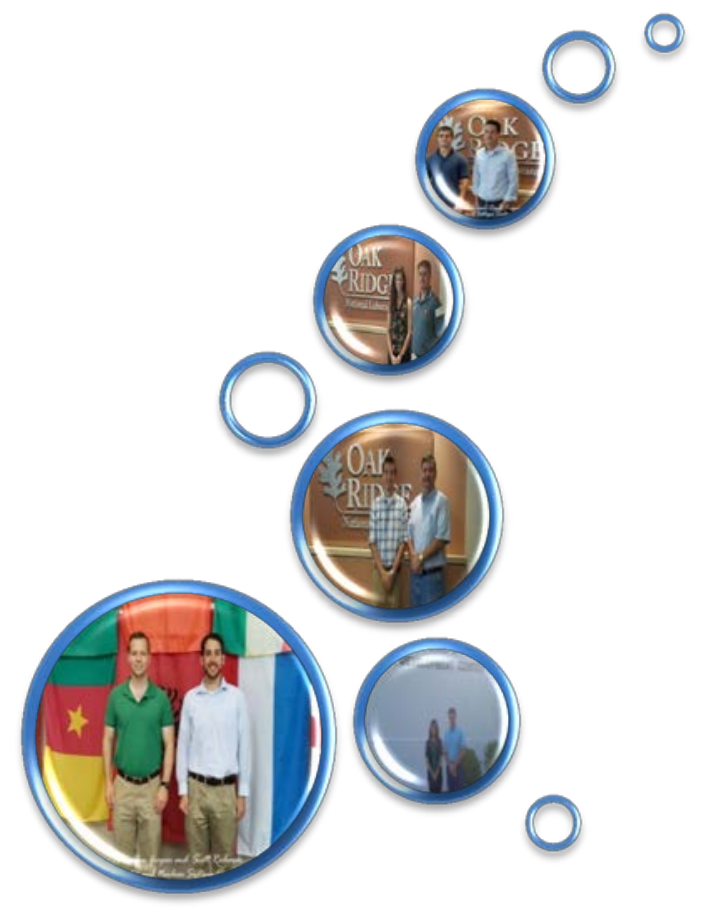

Figure 1. Summer interns with mentors. 


\subsection{ORNL GRADUATE ASSISTANT PROJECTS}

ORNL supported three graduate assistants from Dr. Jason Hayward's nuclear engineering research group at UTK.

- Alexandra Hackett: explored the potential application and implementation of drones for nonproliferation.

- Chris Andrews: supported the Safeguards Lab and research related to holdup measurements.

- Angela Simone: evaluated the prototype the Proportional Technologies, Inc.'s Boron Coated Straws High Level Neutron Coincidence Counter (BCS HLNCC) unit demonstrated at the Joint Research Centre, ISPRA as a benchmark against the ${ }^{3} \mathrm{He}$ tube based ORNL Large Volume Active Well Coincidence Counter (AWCC), as well as seeking ways BCS might be incorporated into future practical designs for field use.

\subsection{ORNL INTERN PROJECTS}

ORNL announced an internal call for intern project proposals and submitted the consolidated list to NPAC for review. ORNL staff submitted requests for a variety of nonproliferation projects that could benefit from intern and graduate assistant support. Of these projects, the following were selected to be supported with OINS funds for FY 2016. All summer interns participate in a Laboratory-wide poster competition at the end of the summer.

- During the school year, Rachel Gaudet transitioned to support Louise Worrall, Ph.D., in the creation and writing of the User's Guide for the International Database of Reference Spectra for the Measurement of Uranium and Plutonium Isotopics. This database acts as an online repository of special nuclear material gamma-ray spectrometry measurements and is the ideal medium for sharing and allowing previous spectra measurements to be used for a variety of applications across a large span of facilities or countries. Once completed, the user's guide will act as a companion while using the database and offer insight on the structure, materials, isotopic codes, detectors, and techniques used in the spectrometry measurements. Through this project, Ms. Gaudet was able to significantly improve her technical communication skills while also gaining perspective on the functionality of an international working group in the safeguards community.

- During the summer of 2016, NCSU student Joseph Cope worked with mentor Vince Jodoin, Ph.D. The United States used ground based air samplers to actively collect fallout during atmospheric testing. Reports on the collections describe the distribution and characteristics of fallout collected at these longer ranges (greater than 10 miles) where volatile samples might be found. ORNL has developed the Defense Land Fallout Interpretative Code DELFIC Fallout Planning Tool for ground collection mission planning under a previous research and development (R\&D) project and has maintained and improved that tool in recent years. Mr. Cope's accomplishments included activities such as: calculating the characteristics of airborne debris at distances greater than 10 miles; reviewing ground based air sampling conducted during U.S. atmospheric testing; reviewing commercial off-the-shelf ground based air sampling equipment; developing an Airborne Debris Collection Planning Tool; and suggesting sampling plans for ground based air samplers for the National Technical Nuclear Forensics Center.

- During the summer of 2016, University of Texas, Austin student Adam Drescher worked with mentor Roger Kapsimalis, Ph.D. on nuclear matters, including nuclear materials characterization by ultra-short-lived fission and activation product measurement. This project involves the 
characterization and method development of a gamma detector system, in line with the pneumatic transfer tube at the Neutron Activation Analysis Laboratory at ORNL's High Flux Isotope Reactor (HFIR) that will allow for the measurement of species with half-lives on the order of $1 \mathrm{~s}$. Such a technique can advance materials accounting and online monitoring of nuclear facilities.

- During the summer of 2016, University of Tennessee, Knoxville student Scott Richards worked with mentor Brandon Grogan, Ph.D. Mr. Richards developed and ran a number of ORIGEN fuel depletion and cooling simulations to calculate the gamma and neutron spectra of the fuel. Each ORIGEN case represented small variations in operating history (e.g., three cycles vs. four, different cycle lengths, varying power levels). Mr. Richards then used the INDEPTH code to solve for the initial enrichment, cooling time, and burnup using the gamma and neutron values. These results help determine how the INDEPTH results are affected by the different variations in the operating histories of the assemblies.

- Graduate assistant Angela Simone continued her work described above as a summer intern in 2016, with mentor Stephen Croft, Ph.D. Ms. Simone won the annual NESLS poster competition with her work entitled, "Characterizing the Oak Ridge Large Volume Active Well Coincidence Counter for Nuclear Safeguards Applications.”

\subsection{INTERN PROGRAM}

ORNL offered the following tours for the interns during the summer of 2016:

- Spallation Neutron Source (SNS),

- Consortium for Advanced Simulation of Light Water Reactors,

- HFIR and Radiochemical Engineering Development Center (REDC),

- Manufacturing Demonstration Facility,

- High Temperature Materials Laboratory, and

- Exploratory Visualization Environment for Research in Science and Technology.

Interns also attended the following OINS Summer Seminar Series via Webinar. These are organized at ORNL by Diana Tucker. Attendance was relatively high this year with interns and mid-career staff attending (as indicated in the chart below). 


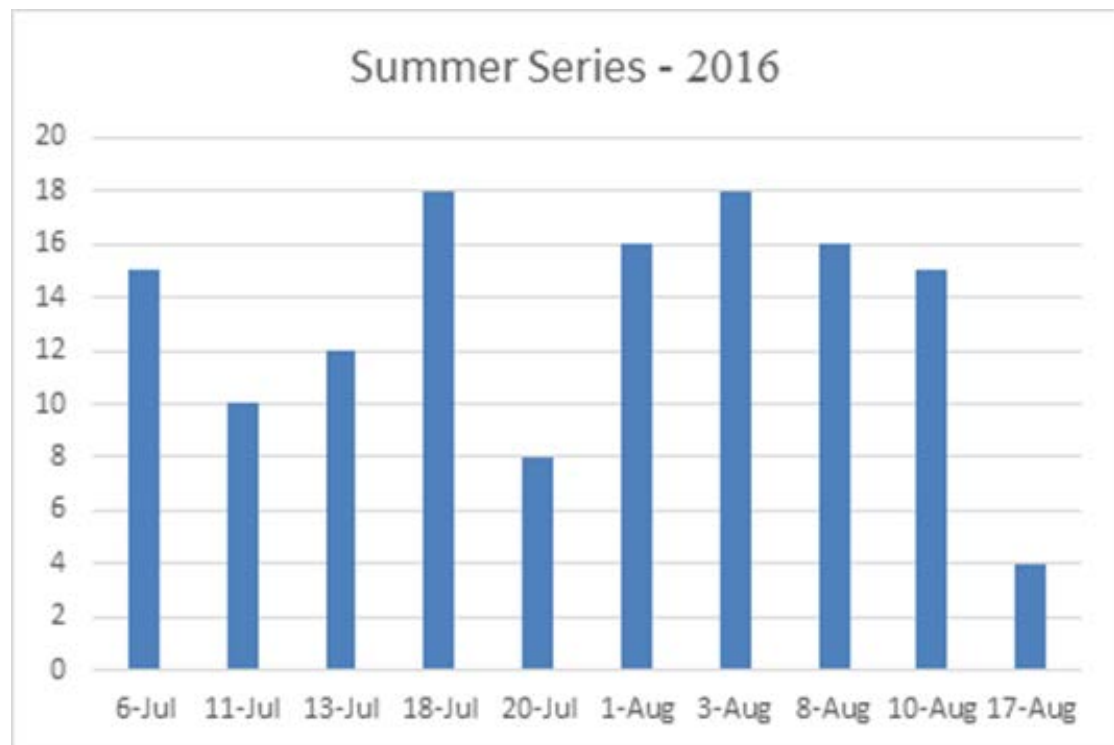

Figure 2. Chart indicating ORNL attendance at the OINS Summer Safeguards Lecture Series.

\section{OINS Summer Safeguards Lecture Series}

July 6 Ray Diaz, BNL and Steve Amundson, BNL, "International Safeguard Project Office and Careers in Safeguards at the International Atomic Energy Agency (IAEA)”

July 11 Yana Feldman, LLNL, “Overview: IAEA and International Safeguards”

July 13 Justin Reed, Argonne National Laboratory (ANL), “Experience of a Safeguards Information Analyst”

July 18 Michael Whitaker, ORNL, "Safeguards at Enrichment Facilities”

July 20 Shirley Johnson, PNNL, "Safeguards at Reprocessing Facilities”

August 1 Michael Browne, LANL, "Fukushima Safeguards Issues”

August 3 Heidi Smartt, Sandia National Laboratories (SNL), “Containment and Surveillance Technologies"

August 8 Ruth Kips, LLNL, “The Life of a Safeguards Inspector”

August 10 Jill Cooley, Y-12 National Security Complex, “Acquisition Path Analysis for State Evaluation"

August 15 George Anzelon, LLNL, "Investigating Undeclared Activities” 


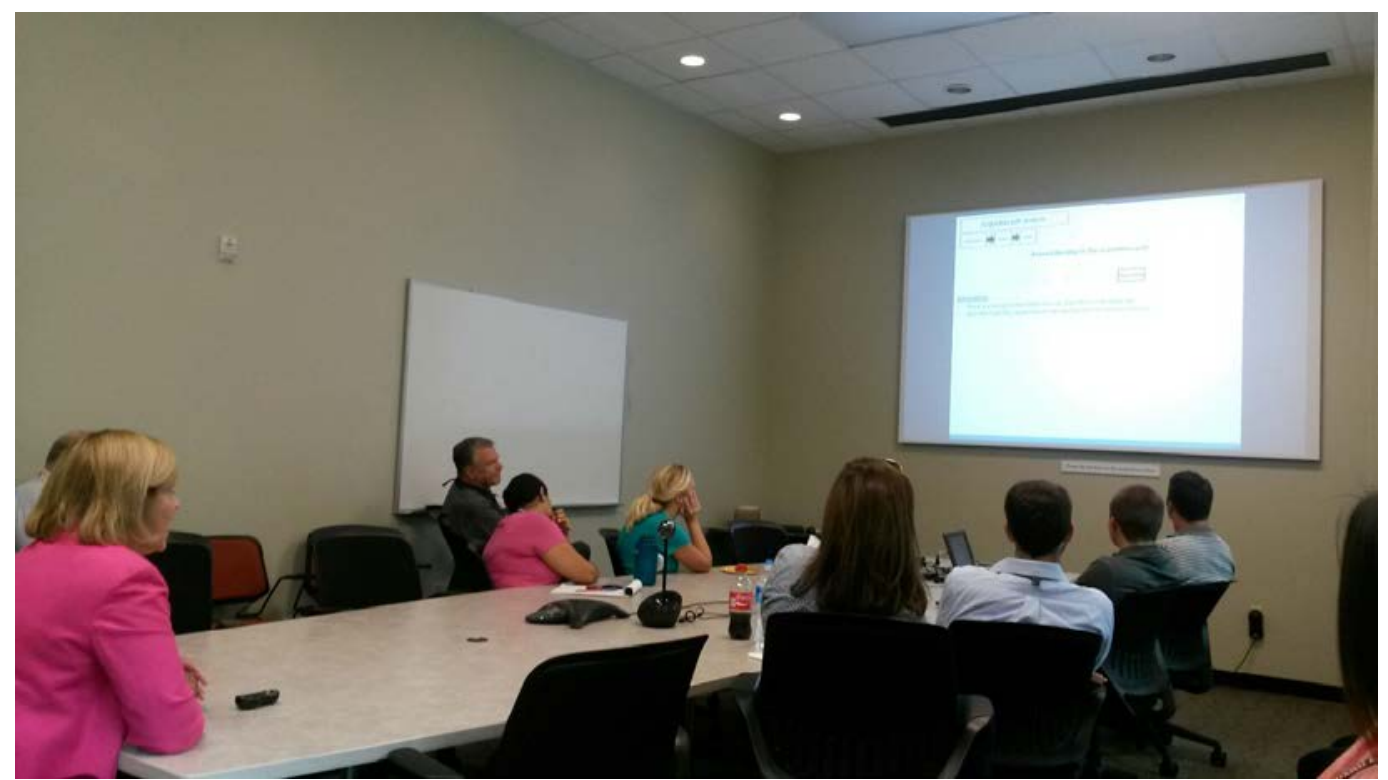

Figure 3. Y-12's Jill Cooley presenting as part of the OINS Summer Safeguards Lecture Series which is broadcast to all national laboratories.

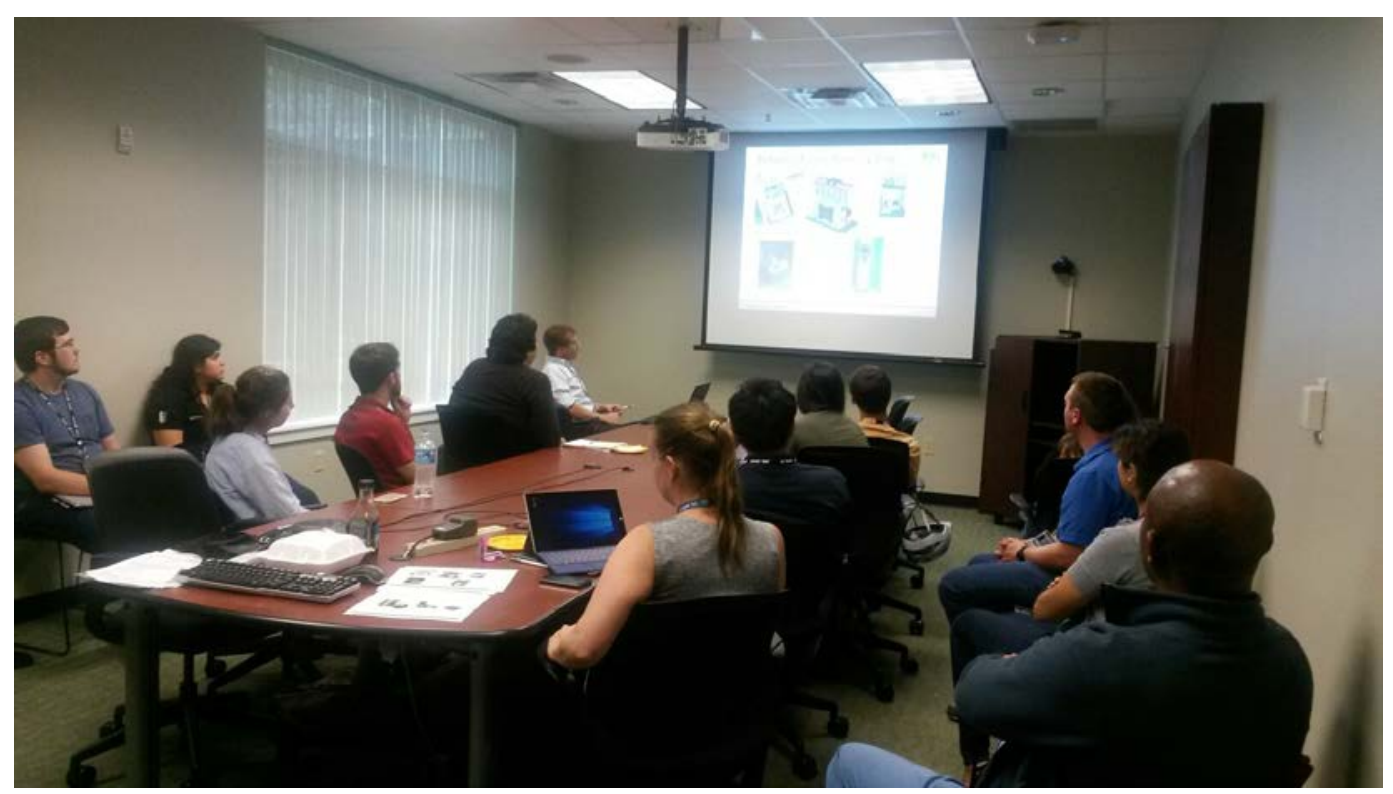

Figure 4. ORNL staff and students attending an OINS Summer Safeguards Lecture Series being broadcast from SNL. 


\section{OINS SUPPORTED POSTGRADUATE APPOINTMENTS AT ORNL}

In FY 2016, OINS postgraduate funds contributed to supporting seven full-time and part-time postgraduate positions at ORNL. The following section summarizes each postgraduate's contribution to nonproliferation and safeguards during his or her time at ORNL.

\subsection{SCOTT STEWART}

Scott Stewart was an Oak Ridge Associated Universities (ORAU) post-master's research associate supporting Jim Garner and Michael Whitaker in the International Safeguards Group of the Nuclear Security and Isotope Technology Division (Fig. 5). He worked with Jim Garner on the Unattended Cylinder Verification Station project, and as part of that effort is working on camera surveillance image encryption and verification. Stewart also supported Garner's work with the General Advanced Review Software product from Canberra for surveillance imagery review, as well as other work with the Genetec software package, which is essentially commercial off-the-shelf security software. Stewart has been successfully hired on as a full time researcher with ORNL in the Safeguards and Security Technologies Group.

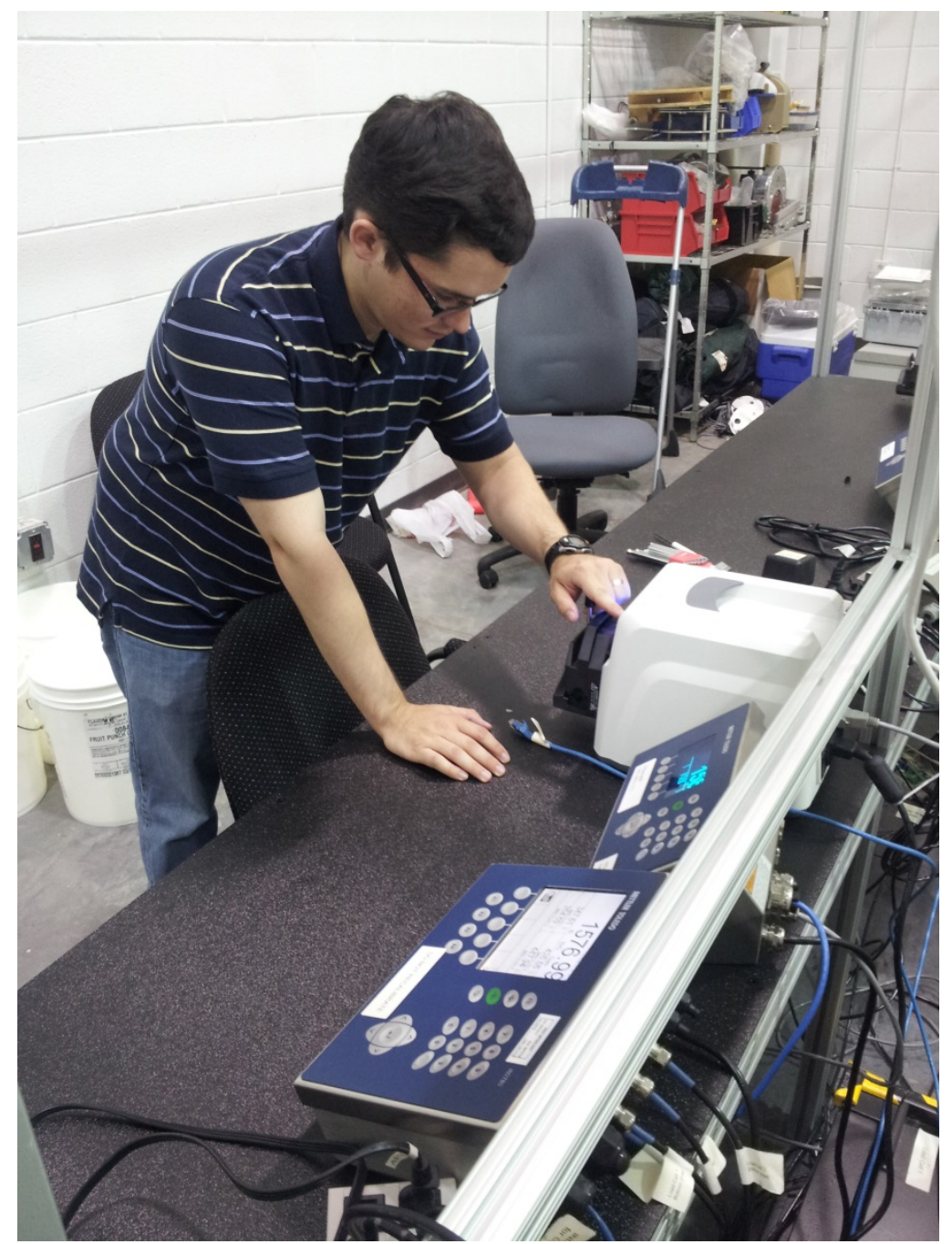

Figure 5. Scott Stewart works on calibrating new equipment. 


\subsection{HANNAH HALE-SALVO}

Hannah Hale-Salvo joined the International Safeguards group of the Nuclear Security and Isotope Technology Division in October 2015. Ms. Hale-Salvo completed her master's in nuclear engineering in December and is currently pursuing a Ph.D. in the UTK Bredesen Center for Interdisciplinary Research and Graduate Education's Energy Science and Engineering program with a focus in Nuclear Energy. Within the International Safeguards Group, Ms. Hale-Salvo works closely with mentor Don Kovacic on Sub-Saharan Africa engagement to support the International Nuclear Safeguards Engagement Program (INSEP). Her focus is on developing workshops and trainings to meet identified needs of partner countries in the region. Ms. Hale-Salvo also supports UTK’s Institute for Nuclear Security and actively seeks synergistic opportunities between ORNL and UTK.

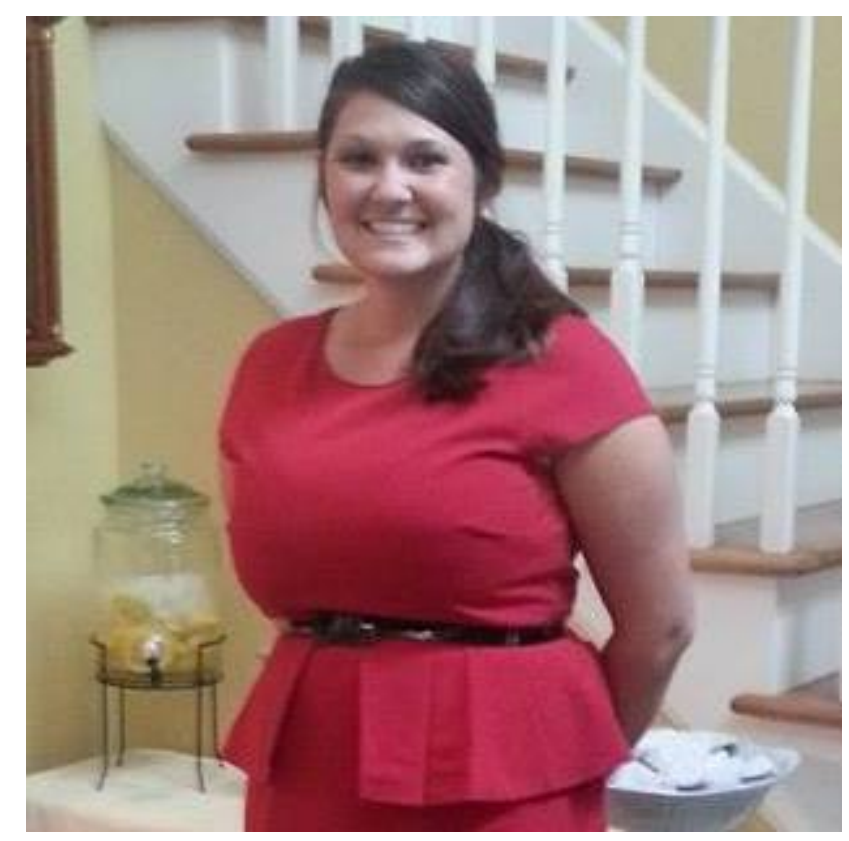

Figure 6. Hannah Hale-Salvo.

\subsection{GAVIN MATTINGLY}

Gavin Mattingly joined the International Safeguards Group after graduating in May 2016 with a bachelor's degree in nuclear engineering from the University of Illinois, Urbana-Champaign. Mr. Mattingly's work focuses on supporting mentor Jim Garner's nuclear safeguards efforts for bulk handling facilities. One of his first tasks has been to develop documentation on use of the Platform Scale Testing Center. The Platform Scale Testing Center can simulate weight profiles observed at $\mathrm{UF}_{6}$ feed and withdrawal stations. His other task has been to develop a plan to study the effects of temperature to measurements made using strain gage based load cells. The aim of this study is to show how load cells would perform if used in the feed and withdrawal stations used to handle $\mathrm{UF}_{6}$. 


\subsection{KATY SNOW}

During her appointment in the ORNL Post-Master's Research Participation Program, Katy Snow worked in the International Safeguards Group of the Nuclear Security and Isotope Technology Division under the supervision of Michael Whitaker. Given that Snow no longer lives near a national laboratory, she has established her own consulting business to continue to pursue her passion for nonproliferation and safeguards issues. ORNL continues to call on her as needed to support international safeguards and international meetings. In FY16, Ms. Snow played a vital role in the transit matching project within OINS Concepts and Approaches. Ms. Snow is taking a leave from the workforce and is closing her business in FY17.

\subsection{ANN PEDERSON}

Ann Pederson works part-time as an ORAU research associate in the International Safeguards Group while completing her law degree at UTK. She assists in research and writing on OINS-related topics. This year Ms. Pederson was an author of the BNL-led concepts and approaches project focused on turnkey a power program. She was the lead for researching and writing about one of the case study countries. She primarily works on nuclear safeguards reporting systems and on a system requirements specification document that provides software developers with discrete and verifiable requirements for comprehensive safeguards nuclear material accountancy reporting and additional protocol reporting. Ms. Pederson plans to leave ORNL for full time employment in the early fall.

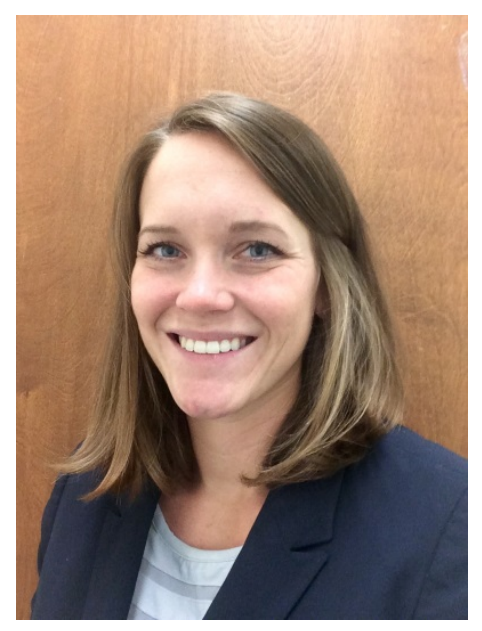

Figure 7. Research Associate Ann Pederson. 


\subsection{ANAGHA IYENGAR}

In August 2016, Anagha Iyengar joined ORNL after two years of service at DOE/NNSA Headquarters with OINS' Safeguards Technology Development Program. Ms. Iyengar is working as an ORAU research associate for the Nuclear Materials Detector and Characterization group of Nuclear Security and Isotope Technology Division under the mentorship of John Mihalczo, Ph.D. Her efforts include simulating measurements with the Nuclear Materials Identification System and in particular fast neutron imaging of special nuclear materials. In addition to imaging, Iyengar will be performing measurements at ORNL, Y-12, LANL and other DOE facilities; she will also participate in the planning of future measurements. Ms. Iyengar is expected to be involved in the assembly and development of measurement systems for use at ORNL and other facilities. As part of her post masters, Ms. Iyengar is also supporting the Safeguards and Security Technology group at ORNL in a project related to source fabrication, and she is also supporting the EURATOM International Safeguards Engagement Program (INSEP) portfolio. Part of her work scope also includes supporting the Nonproliferation Technology Group in Part 810 issues and interdiction activities.

\subsection{SHALINA BOTTORFF}

Shalina Bottorff joined ORNL in July 2016 as a postdoctoral candidate in the Nuclear Analytical Chemistry \& Isotopics Laboratory, under the mentorship of Brian Ticknor, Ph.D. She supports new method development in the ORNL Network of Analytical Laboratories (NWAL) laboratory for Bulk Analysis of Environmental Samples. The IAEA has traditionally requested uranium and plutonium analysis in NWAL samples. ORNL has a long-standing chemical separation and mass spectrometry program in place to perform these analyses. However, the frequency of "special request" samples from the IAEA, which can include thorium and americium measurements and age dating, are increasing across the DOE complex. ORNL currently meets these requests for additional analysis, but the separations, spike schemes, and mass spectrometric analyses are designed on a sample-by-sample basis and are not formalized procedures for IAEA swipe samples. Ms. Bottorff's work will contribute to efficiency gains in both cost and timeliness by developing validated methods for these increasingly common "special requests" from the IAEA. Shalina is also supporting a research project sponsored by NA-241 Safeguards Technology Development where ORNL is developing a method for automated U and Pu separation from environmental swipe samples for NWAL analysis. This method will produce samples suitable for multicollector, inductively coupled plasma mass spectrometry analysis, and can process multiple samples in unattended operation, thereby maximizing throughput and minimizing operating costs. 


\section{OINS HCD PROGRAM SUPPORT}

\subsection{NUCLEAR NON PROLIFERATION INTERNATIONAL SAFEGUARDS EVALUATION AND SUPPORT}

Kim Gilligan reviewed applications for the 2016 Nuclear Nonproliferation International Safeguards (NNIS) Graduate Fellowship Program. ORNL OINS HCD partner universities were well represented in the applicant pool, with several applicants having gone through an ORNL OINS Nonproliferation Workshop with their university. Dr. Gilligan also reviewed two university applications to join NNIS. ORNL did not host an NNIS practicum this year.

\subsection{PROGRAM REVIEW}

On August 15-16, 2016, Kim Gilligan and Ram Venkataraman represented ORNL at the OINS HCD program review. The last program review was in 2013. Dr. Gilligan shared the highlights since the last program review in 2013. Dr. Venkataraman presented on university nonproliferation workshops and the capabilities of the Safeguards Laboratories. The two-day meeting included discussions on best practices and budget processes. 


\section{OINS UNIVERSITY ENGAGEMENT AND NONPROLIFERATION WORKSHOPS}

\subsection{OINS UNIVERSITY WORKSHOPS OVERVIEW}

ORNL hosted several OINS nonproliferation and safeguards workshops throughout the year, the focus of which can vary depending on the group. Attendance at the nine workshops in FY 2016 was 111 students and faculty from 12 universities. The students were evenly divided between undergraduate and graduate degree programs and were predominantly nuclear engineers. In FY 2016, ORNL continued to reach beyond nuclear engineers to reach policy students interested in the science of nonproliferation as well.

Table 1. University Workshop Overview

\begin{tabular}{|l|c|c|}
\hline \multicolumn{1}{|c|}{ University } & $\begin{array}{c}\text { Number of } \\
\text { students and } \\
\text { faculty }\end{array}$ & Dates \\
\hline $\begin{array}{c}\text { Triangle Institute for Security Studies: } \\
\text { - Duke University } \\
\text { North Carolina State University } \\
\text { • University of North Carolina - Chapel Hill }\end{array}$ & 37 & October 15-16, 2015 \\
\hline University of Michigan & 15 & November 16-20, 2015 \\
\hline North Carolina State University & 16 & March 7-10, 2016 \\
\hline Clemson University & 7 & March 14-16, 2016 \\
\hline University of Georgia & 8 & March 21-24, 2016 \\
\hline Texas A\&M University & 9 & April 4-7, 2016 \\
\hline Morehouse University & 10 & April 11-13, 2016 \\
\hline University of Tennessee, Knoxville & 4 & April 18-21, 2016 \\
\hline West Point Military Academy & $\mathbf{1 1 1}$ & April 21-23, 2016 \\
\hline Total number of participants & & \\
\hline
\end{tabular}




\subsubsection{Workbook Supporting Workshops}

In the summer and fall of 2015, Angie Lousteau (with an OINS intern) undertook developing a workbook to support the university OINS Nonproliferation Workshops. As a newly minted staff member in FY16, Scott Stewart took over the lead on the project and brought the workbook to completion in the summer of FY16. The workbook is intended to aid the participants throughout the workshop, as well as to be a reference when they return to their universities. It was used in pilot form in the spring workshops this year. The workbook includes topics such as:

- International Safeguards,

- Nuclear Physics and Measurement Fundamentals,

- Handheld Detectors,

- Uranium Enrichment Measurements,

- Radiation Portal Monitors,

- In situ Object Counting System (ISOCS),

- Active Well Coincidence Counters (AWCC), and

- Uranium Holdup Measurements.

\subsubsection{Study of Workshop Effectiveness}

This year, Bernie Kirk was brought in to meet with students and faculty during each OINS nonproliferation workshop. Ms. Kirk was charged with identifying the strengthens and weaknesses of the workshop and drafting recommendations on how to improve the workshops. The workshops have always been well received, but after more than five years it was time to assess their effectiveness. Ms. Kirk's recommendations included having prerequisites for the workshops so that some presentation time can be diverted to exercises. This can be accomplished by sending students and faculty internet links to the appropriate OINS tapped presentations. This and other recommendations will be implemented in FY17.

\subsection{THE UNIVERSITY OF TENNESSEE, KNOXVILLE}

Staff from ORNL's Safeguards and Security Technology Group led a hands-on laboratory training course for graduate students from UTK. The class had four participants and took place in ORNL's Safeguards Expansion Laboratory over four days. The first two days were focused on the concepts and measurements using the ${ }^{252} \mathrm{Cf}$ shuffler. The second half of the course focused on the segmented gamma scanner (SGS). The application for safeguards using these techniques was discussed in conjunction with the hands-on activities. By completing the course, students took away the knowledge to decide when using the ${ }^{252} \mathrm{Cf}$ shuffler or SGS would be appropriate for specific assays. Safeguards instrumentation and software provided the students with a practical understanding of a number of nondestructive assay (NDA) techniques used for analyzing special nuclear material (SNM). 


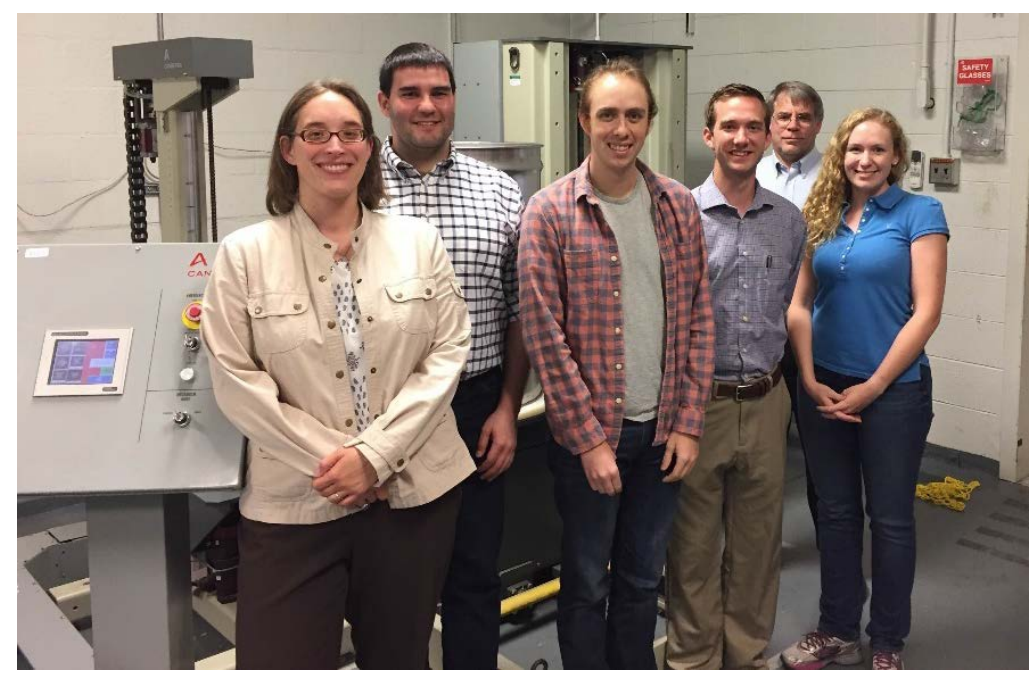

Figure 8. ORNL staff Susan Smith (left) and Bob McElroy (second from right) with UTK nuclear engineering students.

\subsection{MOREHOUSE COLLEGE}

In April, Morehouse College sent eight undergraduate physics students and two physics professors to ORNL for a two-day workshop on nonproliferation NDA training. The students were given lectures on nuclear nonproliferation and the role that the IAEA plays in ensuring nonproliferation. They participated in several exercises in the Safeguards Laboratory that included the use of handheld detectors and a radiation portal monitor. They also participated in tours of the HFIR and the REDC, SNS, Graphite Reactor, and the ORNL supercomputing facilities. This and future workshops with historically black colleges and universities will help encourage minority students to pursue nonproliferation- and safeguards-related careers (Fig. 9).

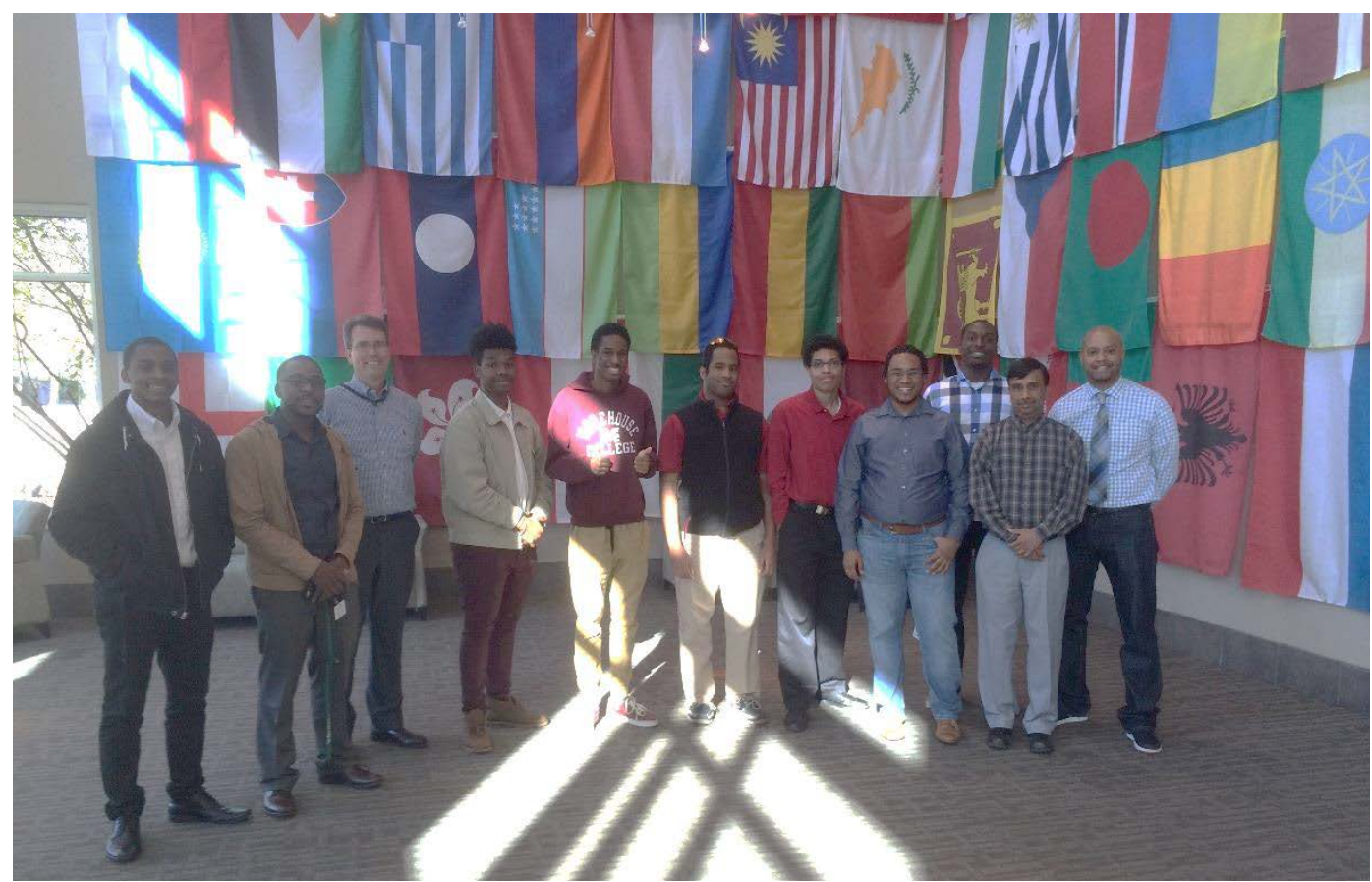

Figure 9. Morehouse College Students at ORNL for an OINS Nonproliferation Workshop. 


\subsection{THE UNIVERSITY OF MICHIGAN}

In 2015, the University of Michigan visited for several days to participate in an OINS Nonproliferation Workshop. The five-day class consisted of both lectures and valuable hands-on experience with safeguards instrumentation and software that provided the students with an introduction to numerous NDA techniques used for analyzing nuclear material. In addition, as part of the class, students attended several technical tours including the SNS, ORTEC, and the Graphite Reactor.

Topics covered during the class included the following:

- Evolution of the IAEA Safeguards System

- Uranium enrichment measurements using an HM5 with NaIGEM, WINU235, and uranium/plutonium detection system

- Uranium holdup measurements

- Neutron coincidence counting using an AWCC

- ISOCS measurements

- Radiation portal monitors

- Portable NDA instrumentation operation, including

— the FLIR Interceptor and HM5 (Identifinder)

- the Canberra InSpector 1000

— the Ortec Detective

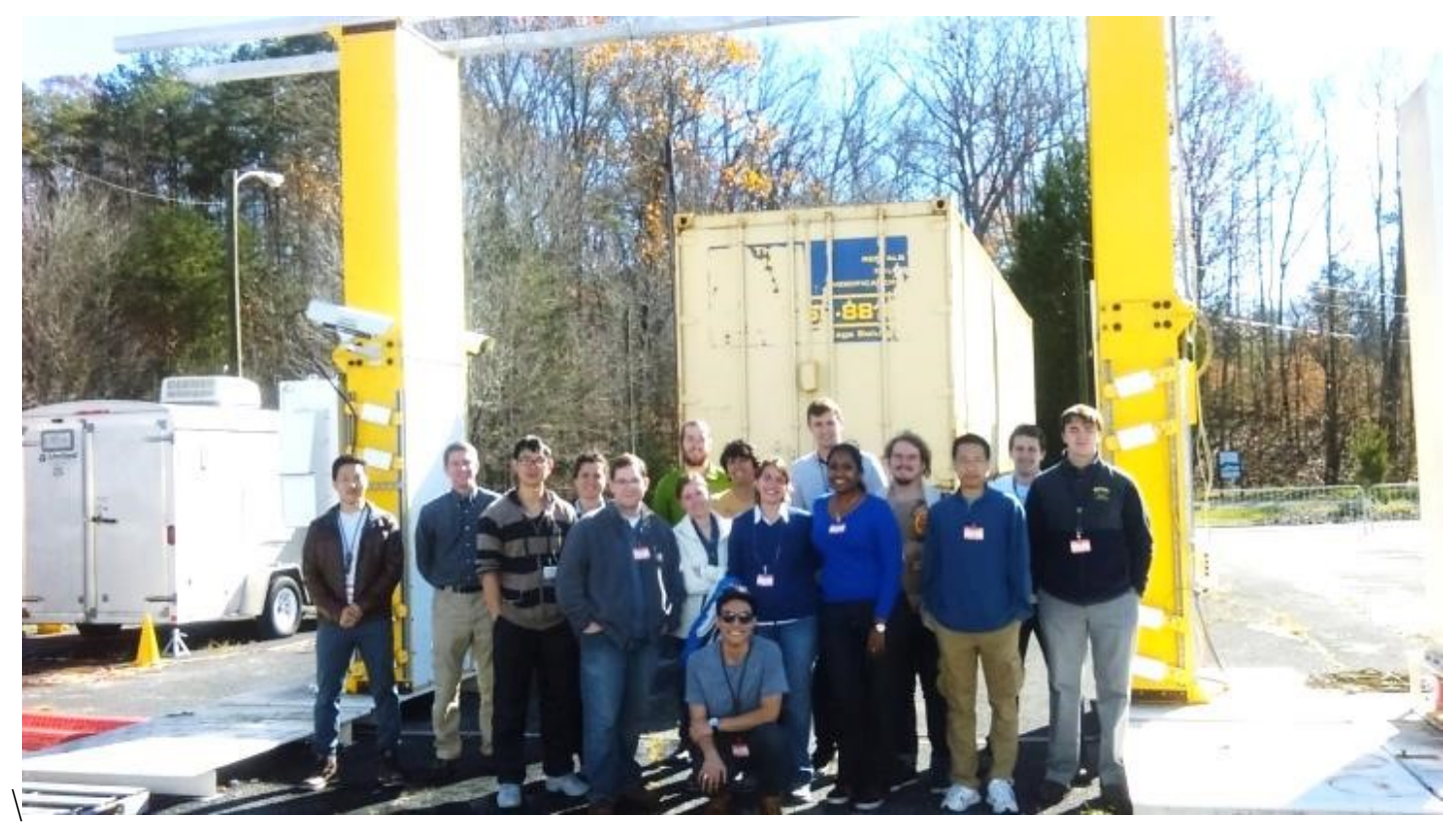

Figure 80. Alex Enders with the UM class at the portal monitor test bed. 


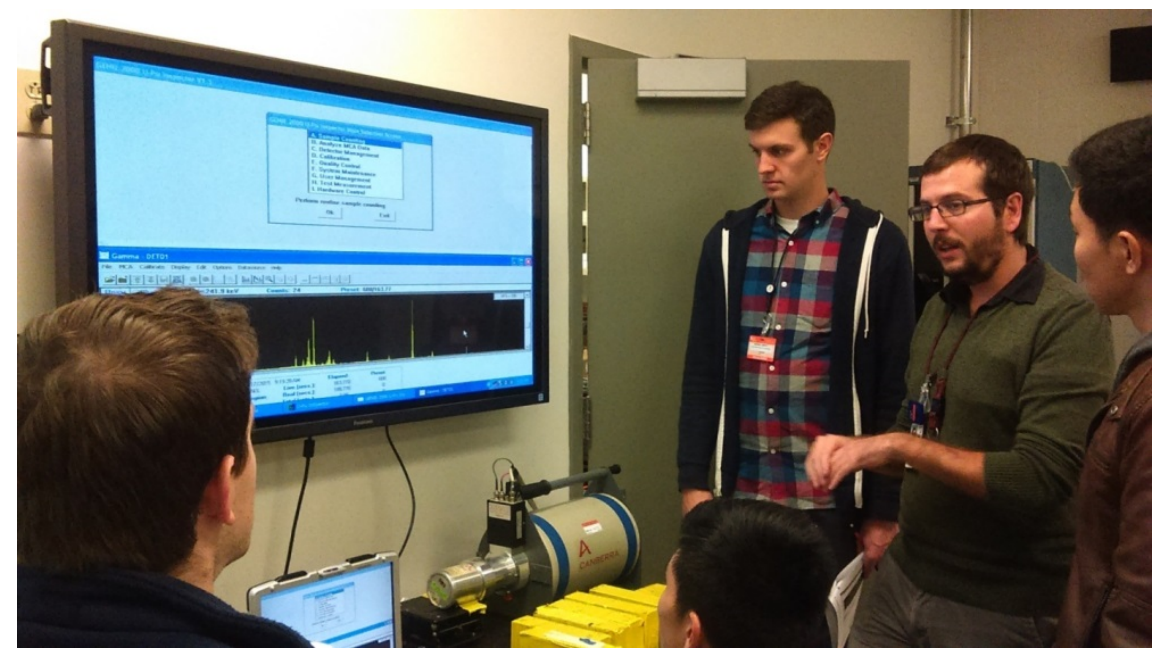

Figure 91. Andrew Nicholson assists UM with taking an NDA measurement.

\subsection{CLEMSON UNIVERSITY}

Staff from the Safeguards and Security Technology Group and the International Safeguards Group hosted a group of six nuclear engineering graduate students and one faculty member from Clemson University (Figure 12) for an OINS Nonproliferation Workshop (March 14-16, 2016). The three-day class consisted of both lectures and valuable hands-on experience with safeguards instrumentation and software that provided the students with an introduction to numerous NDA techniques used for analyzing SNM.

Topics covered during the class included the following:

- Uranium enrichment measurements using an HM5 with NaIGEM, WINU235, and uranium/plutonium detection system

- Uranium holdup measurements

- IAEA Safeguards

- ISOCS measurements

- Radiation portal monitors

- Portable NDA instrumentation operation, including

— the FLIR Interceptor and HM5 (Identifinder)

- the Canberra InSpector 1000

— the Ortec Detective

In addition, as a part of the class, the students attended several technical tours including ORTEC, SNS, HFIR, REDC, and the Graphite Reactor. 


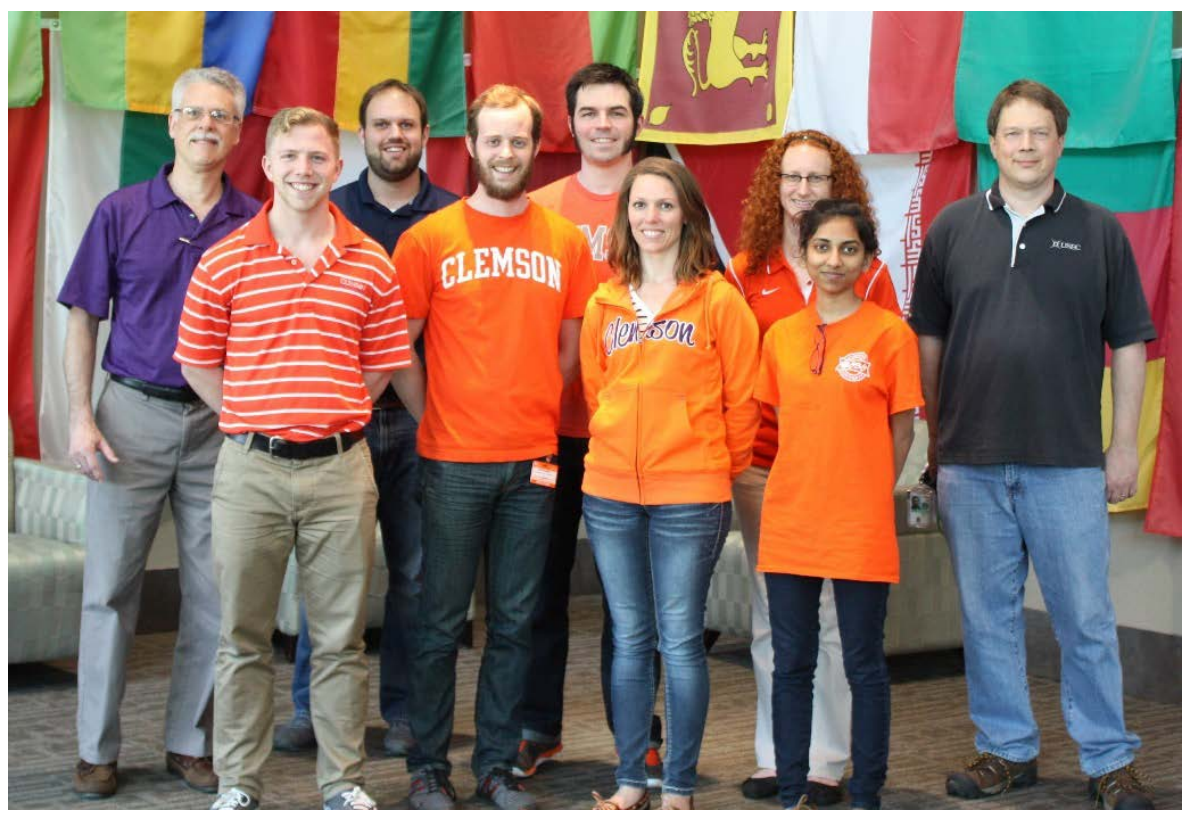

Figure 10. Clemson Students with Professor Timothy Devol and ORNL staff Greg Nutter and Steve Cleveland.

\subsection{THE UNIVERSITY OF GEORGIA}

Based on the success of the previous years, students from the University of Georgia returned to ORNL for another OINS Nonproliferation Workshop. ORNL hosted the group of six students from March 21-24, 2016. The workshop began with a discussion of nuclear nonproliferation and the important role played by the IAEA in attaining nonproliferation goals. As the four-day class continued, students participated in discussions of Design Information Questionnaire/Design Information Verification, environmental sampling, the Democratic People's Republic of Korea, and nuclear material accounting and control. They were able to learn the basics of NDA and use detectors to search for undeclared nuclear materials, and also were able to learn how these NDA techniques could be applied to SNM. In addition to the class, students participated in tours of the HFIR, REDC, Y-12 National Security Complex, and the Graphite Reactor. 


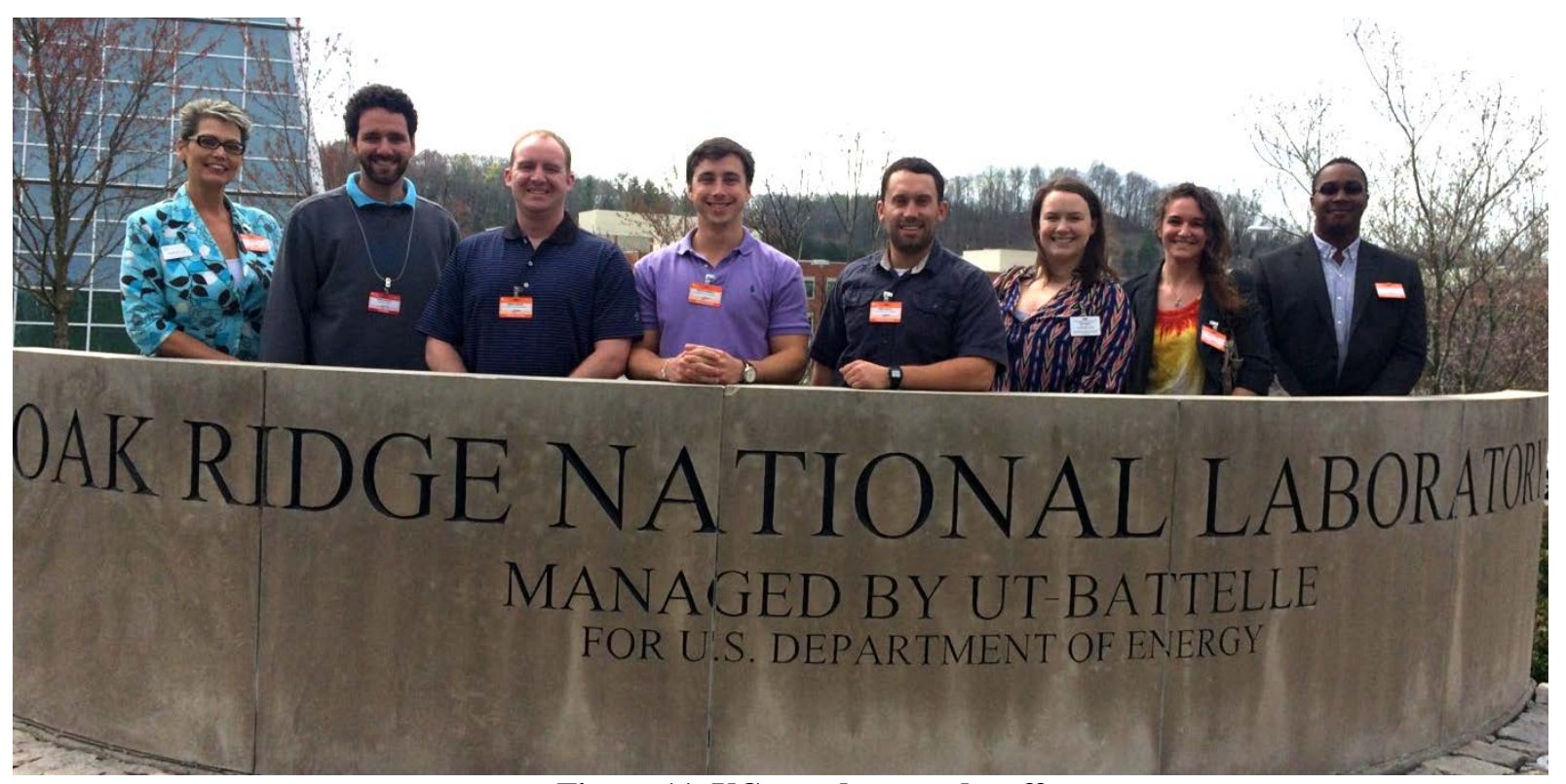

Figure 11. UGa students and staff.

\subsection{TEXAS A\&M UNIVERSITY}

Students and faculty from Texas A\&M University attended an OINS Nonproliferation Workshop at ORNL April 4-7, 2016 (Figure 14). This workshop included five graduate-level nuclear engineering students, three graduate-level policy students, and one faculty member.

Topics covered during the class included:

- Material accounting and control

- Uranium enrichment measurements using an HM5 with NaIGEM, WINU235, and U/Pu detection system

- Uranium holdup measurements

- Neutron coincidence counting using an AWCC

- ISOCS measurements

- Radiation portal monitors

- Portable NDA instrumentation operation, including

— the FLIR Interceptor and HM5 (Identifinder)

— the Canberra InSpector 1000

- the Ortec Detective.

In addition, as a part of the class, students attended several technical tours including the HFIR, REDC, the Spallation Neutron Source, and the Graphite Reactor. 


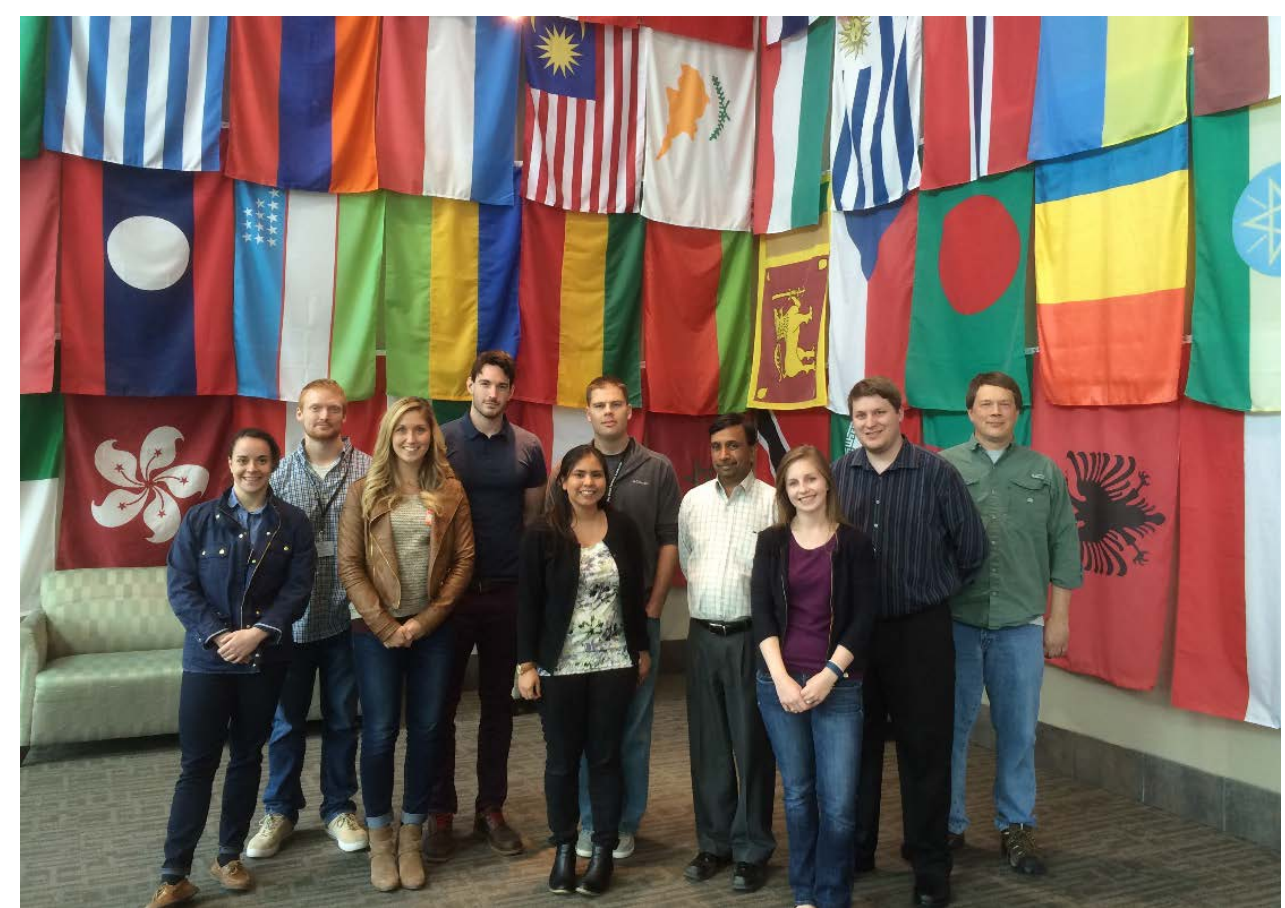

Figure 12. Ram Venkataraman and Greg Nutter stand with the Texas A\&M workshop participants.

\subsection{TRIANGLE INSTITUTE FOR SECURITY STUDIES}

A unique workshop in ORNL OINS HCD is focused on upper level and graduate policy and analysis students. Thirty-seven Triangle Institute for Security Studies (TISS) students and professors from Duke University, University of North Carolina, North Carolina Central University, and NCSU participated in a nuclear nonproliferation workshop led by Nuclear Security and Isotope Technology Division staff on October 15-16, 2015. The agenda included time at the Y-12 National Security Complex and understanding the technology at ORNL supporting threats facing the nonproliferation world today (Fig. 15-16). Continuing on the success from last year's workshop with TISS, this year offered more valuable discussions and exercises designed to showcase the breadth of the international safeguards field. 


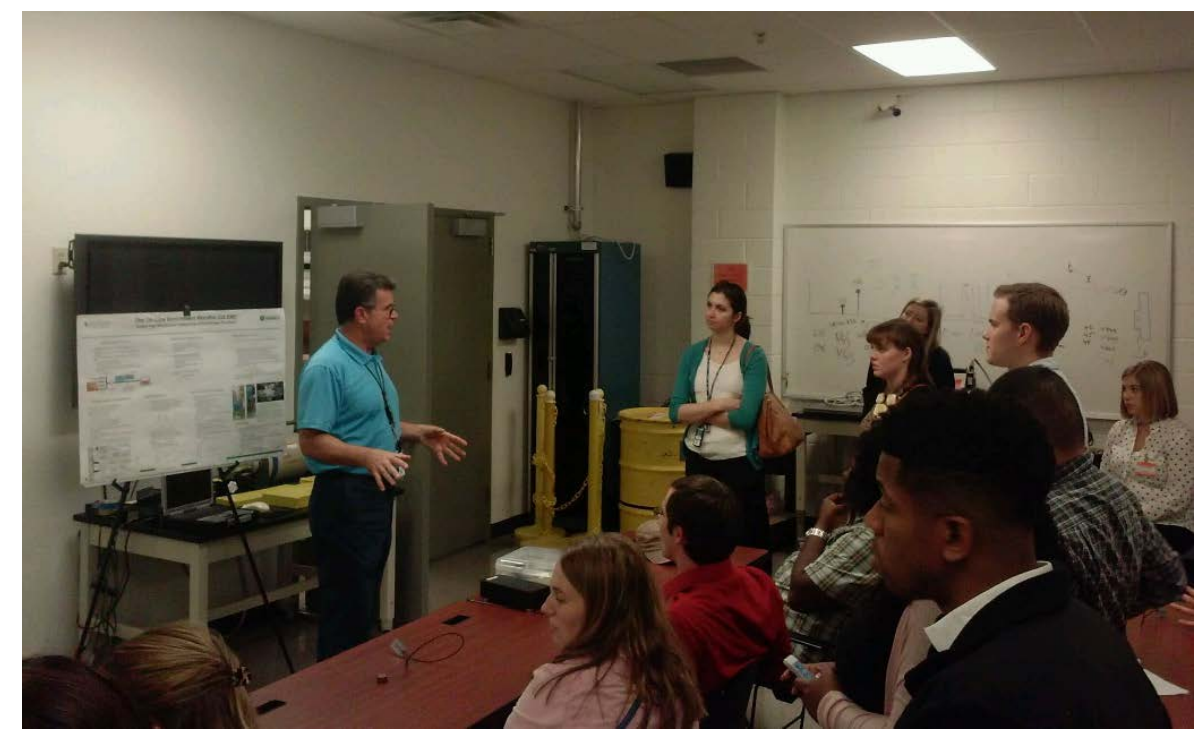

Figure 13. Chris Pickett speaking with TISS participants about IAEA seals.

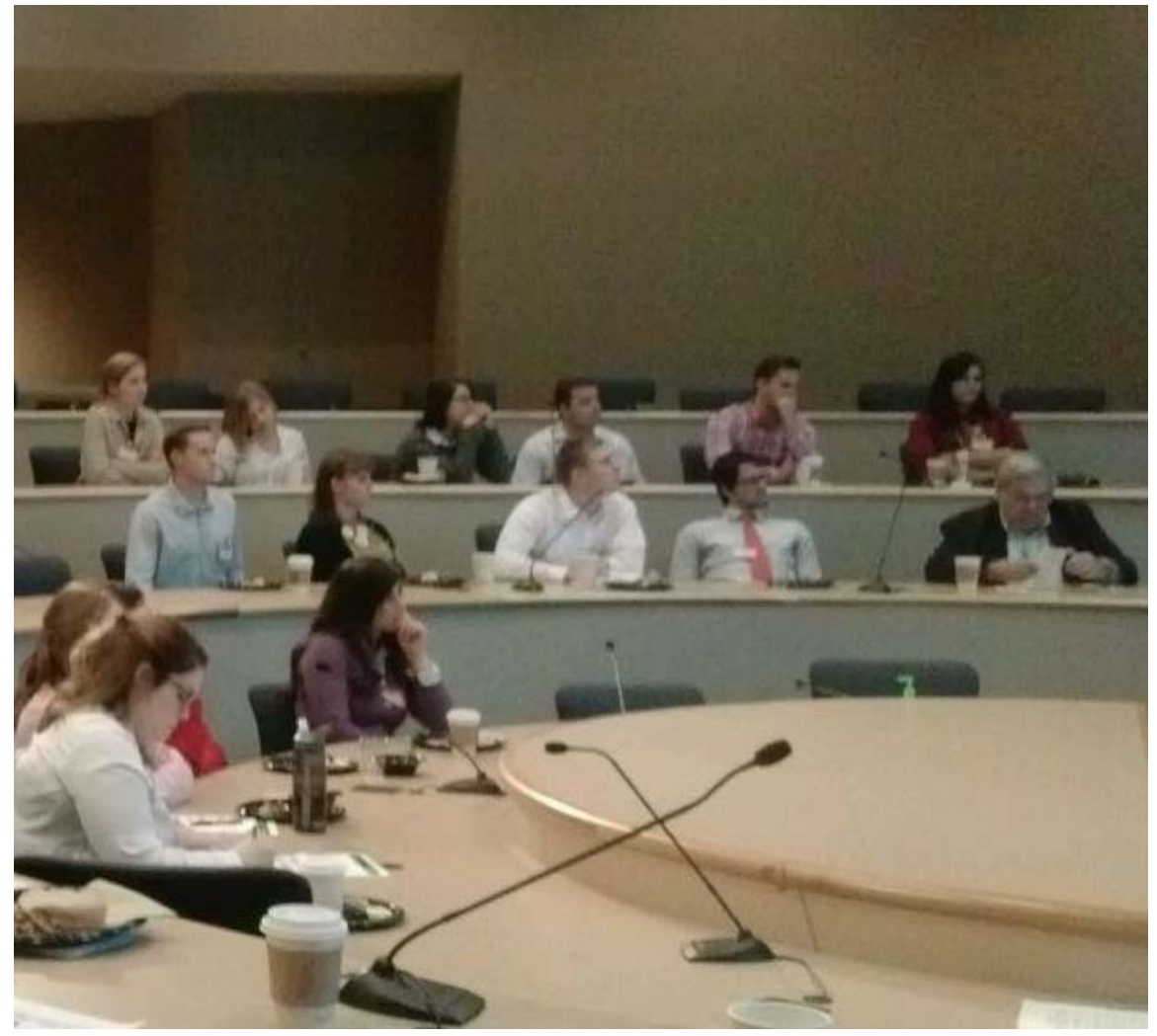

Figure 14. TISS participants.

\subsection{NORTH CAROLINA STATE UNIVERSITY}

Previously, ORNL OINS HCD created a series of taped lectures of safeguards and nonproliferation experts that are still used in university courses. In NCSU's "Nuclear Nonproliferation and Safeguards 
Technology and Policy” course, students watch the lectures and then develop questions for the subject matter experts. Professor John Mattingly collects these questions and submits them to the subject matter experts at ORNL. The students are then able to have a live video teleconference with these experts at their next class session. This year, NCSU also requested three new lectures and updates to two existing lectures. A list of OINS-taped lectures and teleconferences with ORNL subject matter experts is provided as follows (with the new and revised topics indicated).

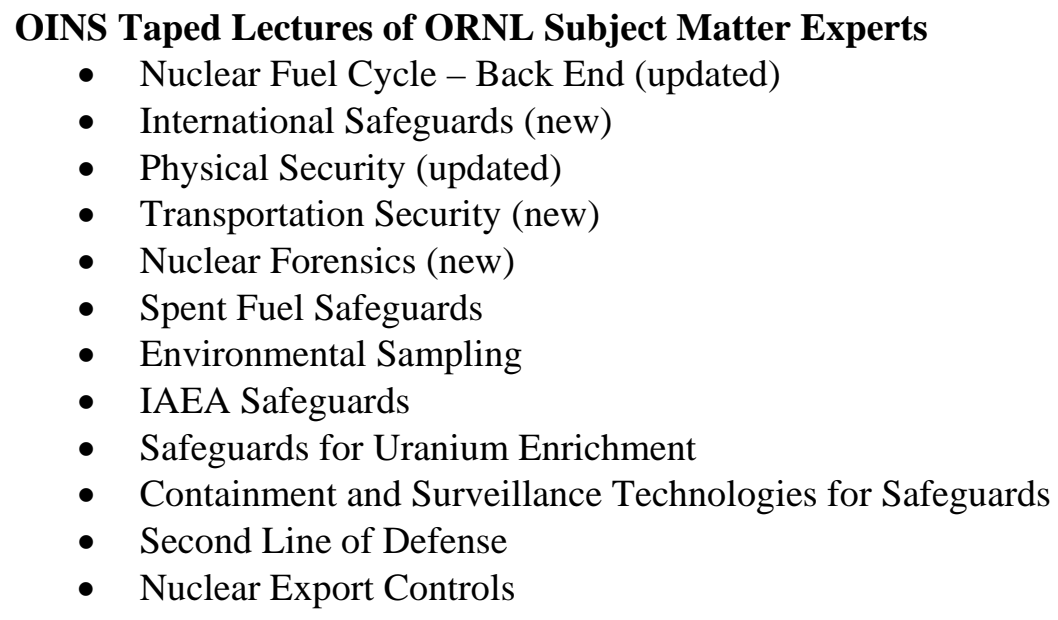

\section{Live Q\&A via Video Teleconference with ORNL Subject Matter Expert}

- State System of Accounting for and Control of Nuclear Material and Safeguards

- Nuclear Fuel Cycle: Back End

- Safeguards Implementation at ORNL

- Physical Security

- Uranium Enrichment

- Safeguards for Spent Fuel

- Containment and Surveillance

- Nuclear Export Controls

- Nuclear Forensics

- Transportation Security

From March 7-10, 2016, fifteen students and one faculty member from NCSU participated in an OINS nuclear nonproliferation workshop hosted by ORNL-HCD and led by the Nuclear Security and Isotope Technology Division (Figures 17-19). The students were a mix of upper-level undergraduate students and graduate students who were studying nuclear engineering and/or policy. The four-day class included lectures and interactive, hands-on exercises that provided students with experience using various NDA techniques and equipment that can be used when analyzing SNM.

Topics covered during the class included the following:

- Uranium enrichment measurements using an HM5 with NaIGEM, WINU235, and uranium/plutonium detection system

- Uranium holdup measurements

- IAEA Safeguards

- ISOCS measurements

- Radiation portal monitors

- Portable NDA instrumentation operation, including 
— the FLIR Interceptor and HM5 (Identifinder)

- the Canberra InSpector 1000

- the Ortec Detective

In addition, as a part of the class, the students attended several technical tours including SNS, HFIR, REDC, and the Graphite Reactor.

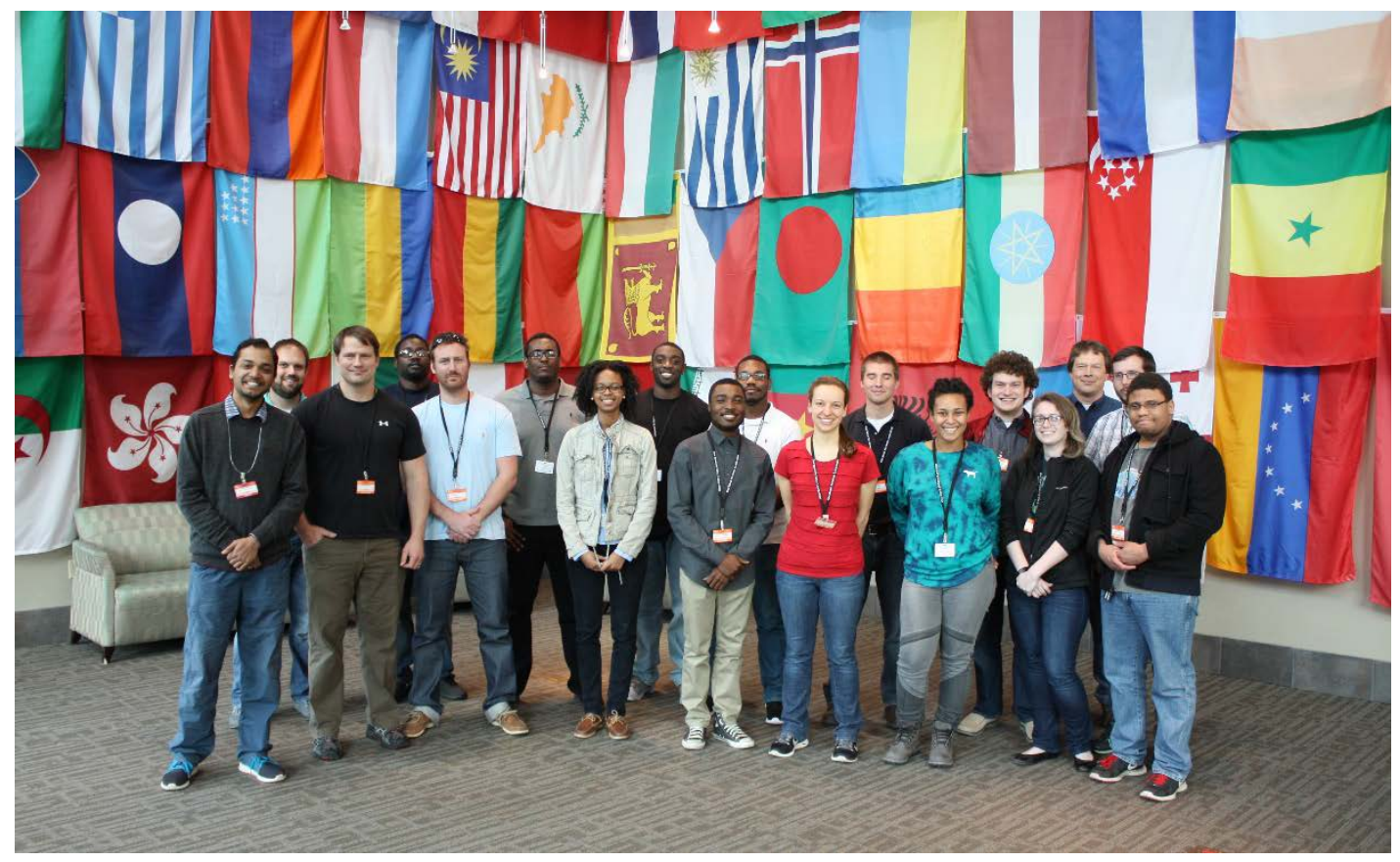

Figure 15. Steve Cleveland and Andrew Nicholson stand with the NCSU workshop participants.

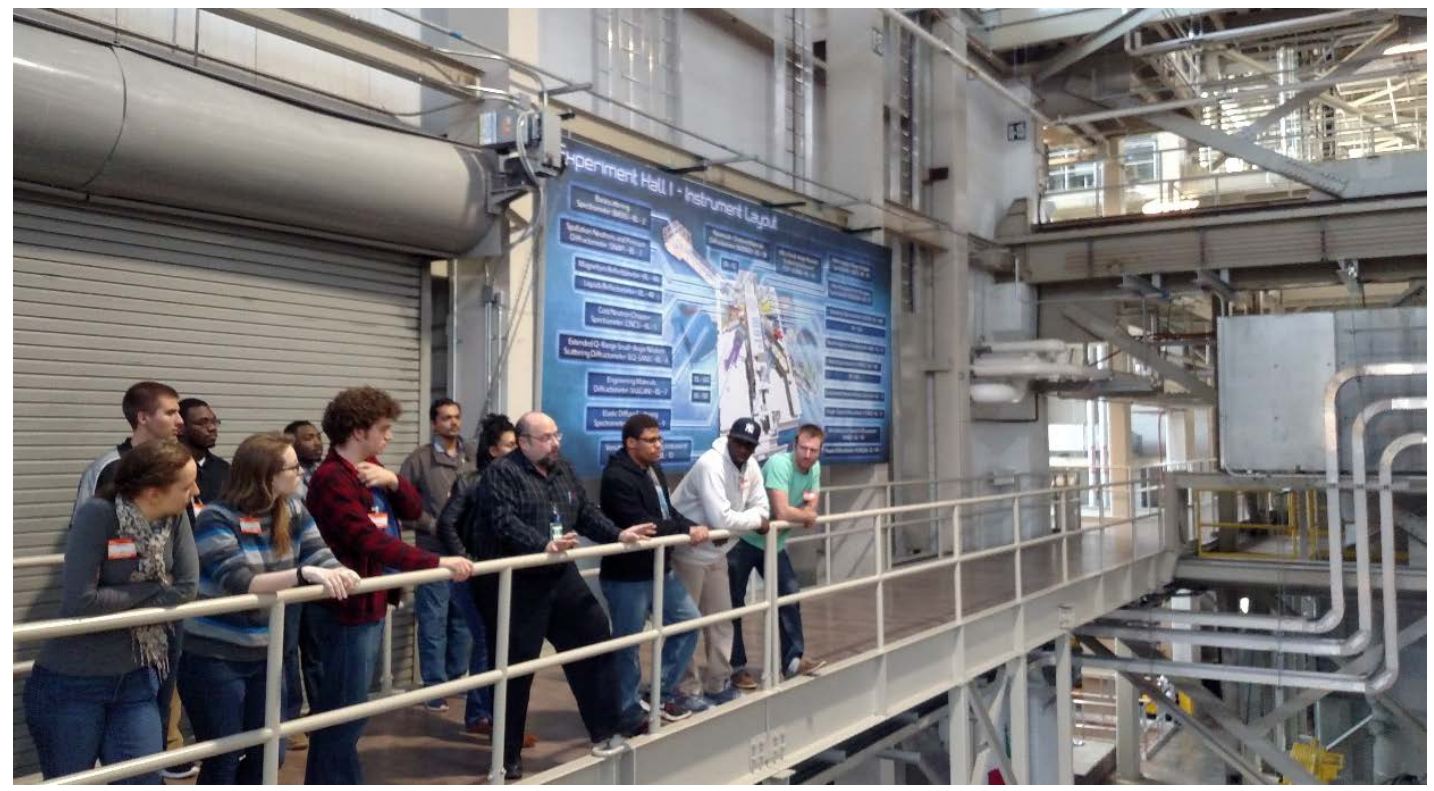

Figure 16. NCSU students on the SNS tour. 


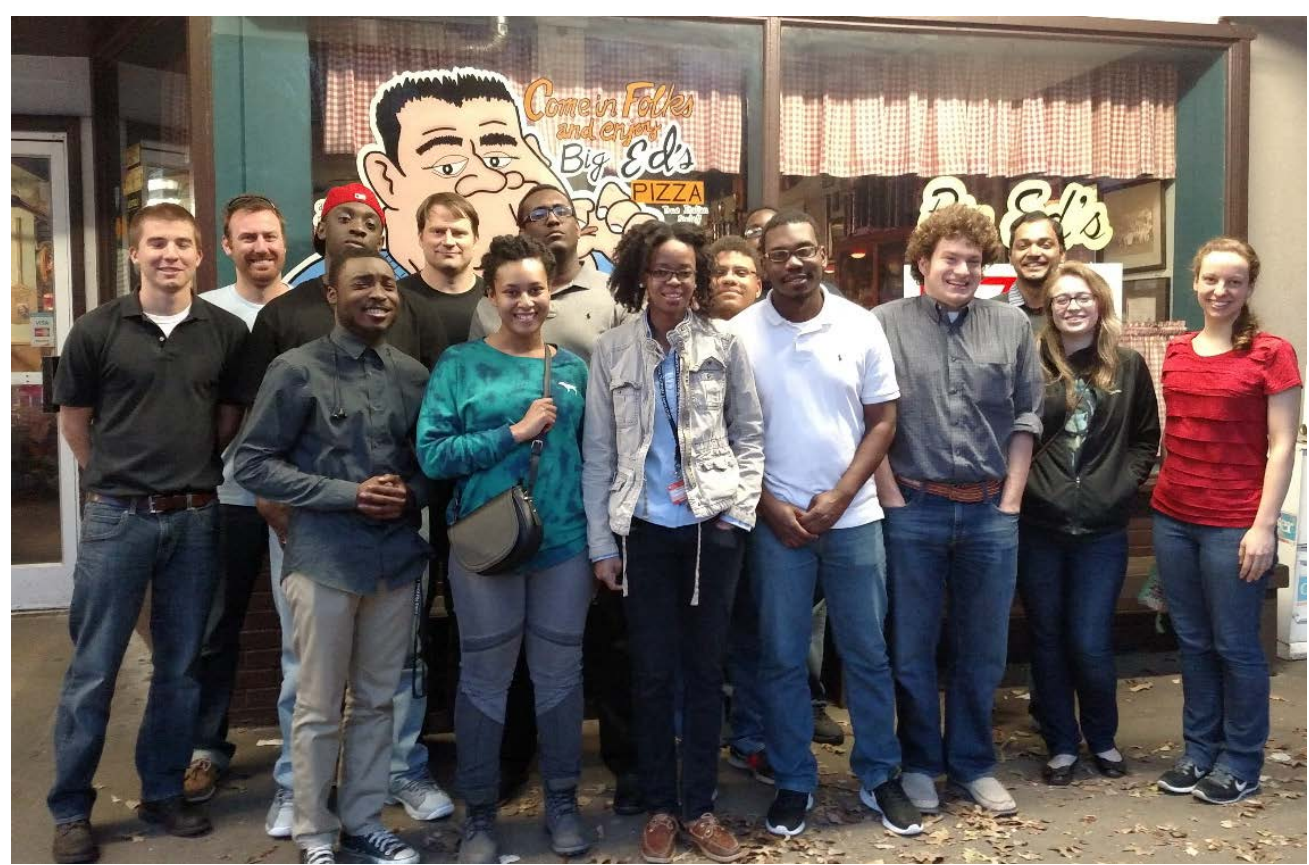

Figure 19. NCSU participants after enjoying Big Ed's Pizza in Oak Ridge.

\subsection{THE UNITED STATES MILITARY ACADEMY AT WEST POINT}

In April, West Point sent three cadets and two faculty members to ORNL for a three-day OINS nonproliferation workshop. Participants were undergraduate physics and nuclear engineering students. The cadets were given lectures on nuclear safeguards and nonproliferation, as well as techniques for ensuring that safeguards requirements are met. They participated in several exercises in the Safeguards Laboratory that included the use of handheld detectors and a radiation portal monitor. They also participated in tours of the HFIR and the REDC, the Graphite Reactor, and the SNS. This and future workshops with military-focused academies and colleges will encourage future military servicemen and women to incorporate nonproliferation- and safeguards-related goals into their careers. Based on the success of this pilot workshop, it is anticipated that West Point will return with the nuclear engineering class ( 15 cadets) in the fall of 2016. 


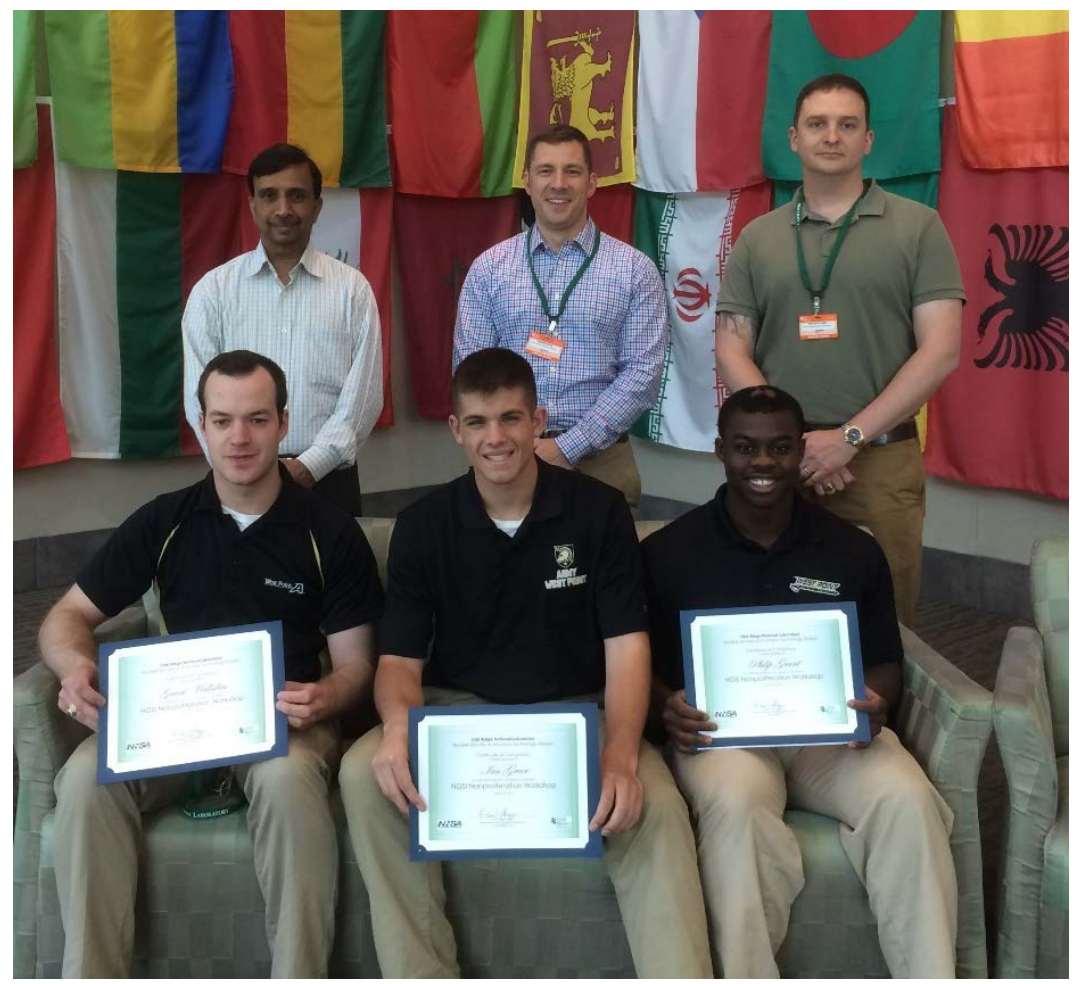

Figure 170. West Point Faculty and Cadets with ORNL's Ram Venkataraman. 


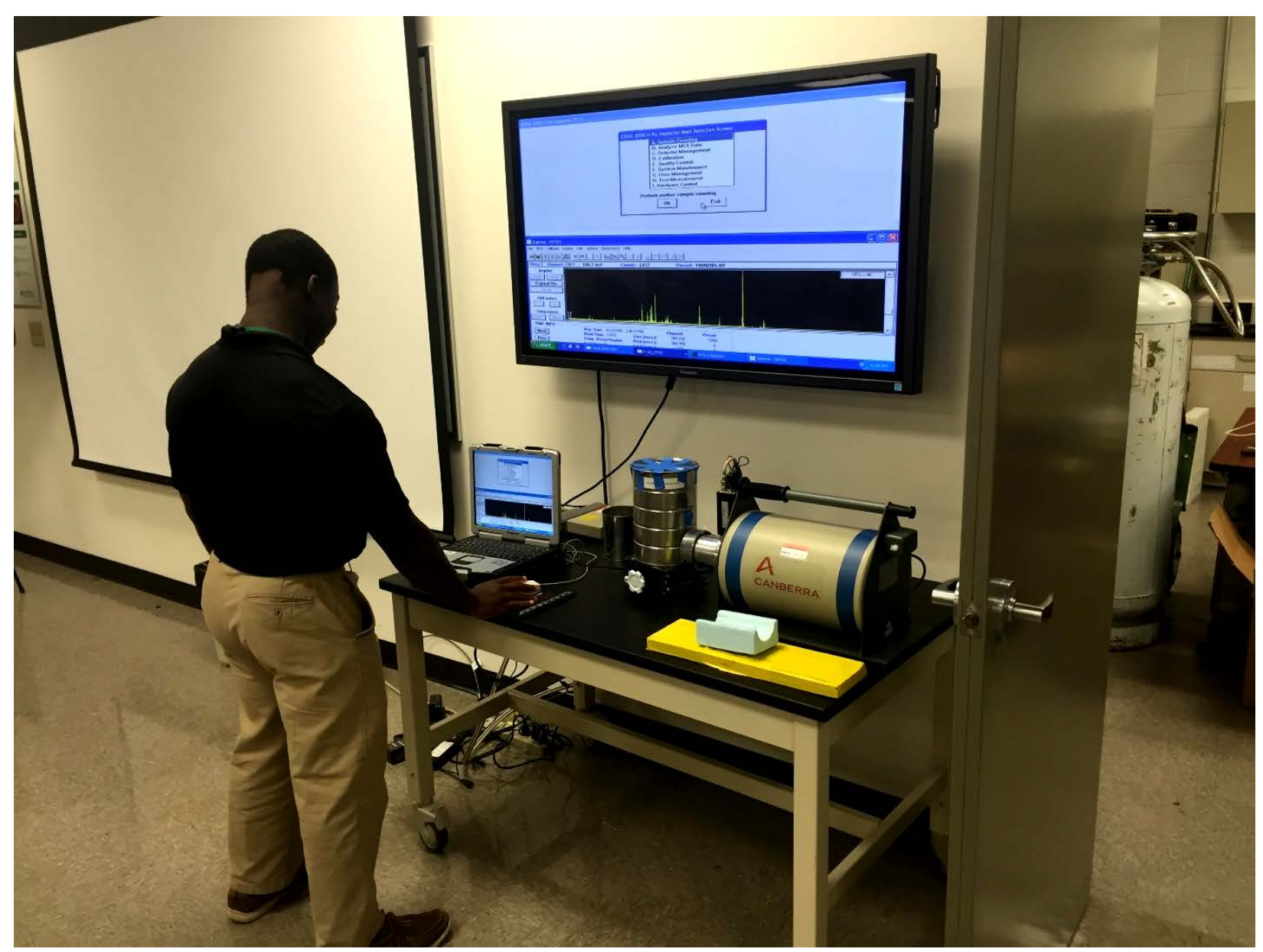

Figure 181. West Point cadet taking an NDA measurement in the Safeguards Laboratory. 


\section{PROFESSIONAL DEVELOPMENT}

\subsection{NEXT GENERATION SAFEGUARDS PROFESSIONAL NETWORK ACTIVITIES}

\subsubsection{NGSPN Workshop}

In September 2016, ORNL's Steve Cleveland and post graduate fellow Gavin Mattingly participated in the Next Generation Safeguards Professional Network (NGSPN) meeting. The workshop was a chance to network with other young safeguards professionals from across the DOE laboratory complex, as well as to learn about the nonproliferation capabilities and resources at BNL. The workshop included presentations, tours, a Radiological Assistance Program consequence management exercises, and an Additional Protocol complementary access exercise.

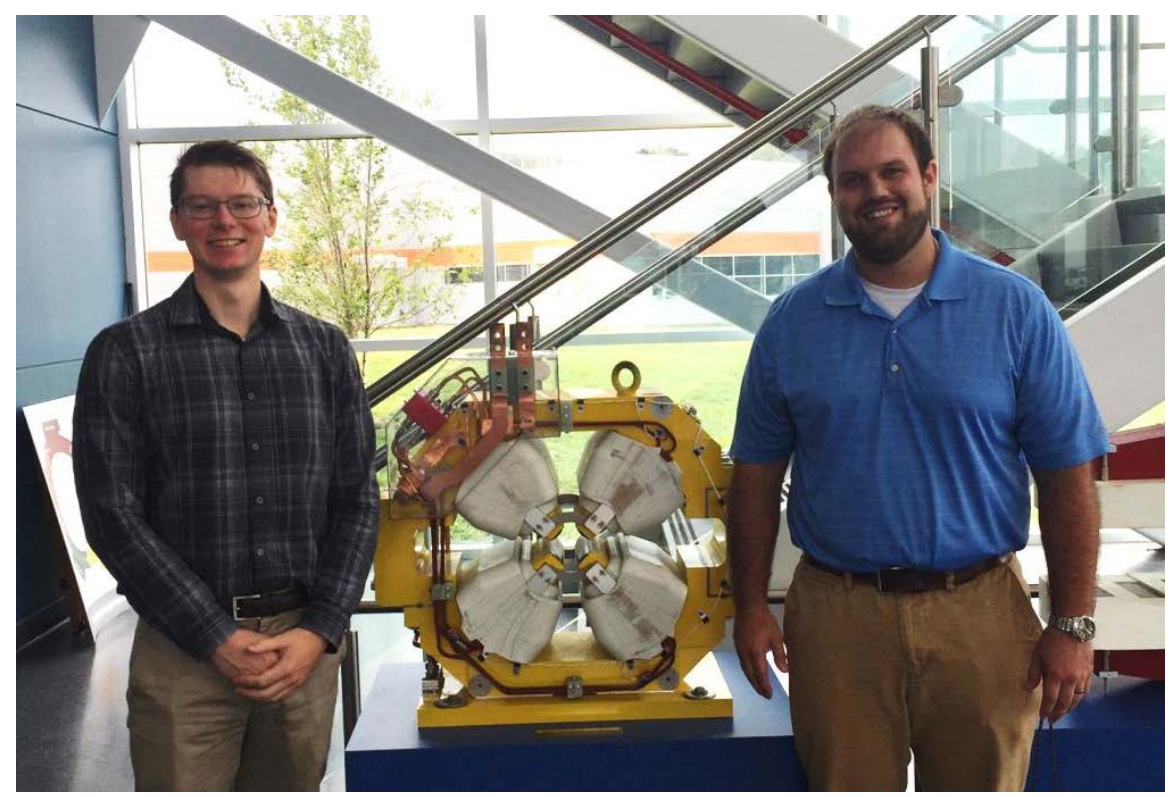

Figure 192. Gavin Mattingly and Steve Cleveland at the NGSPN Meeting at BNL.

\subsubsection{NonproliferationPortal.com}

ORNL's Louise Worrall is the point of contact for the portal effort being spearheaded by INL. Louise was the lead for the NDA section of the Nonproliferation Portal which was published in FY16. 


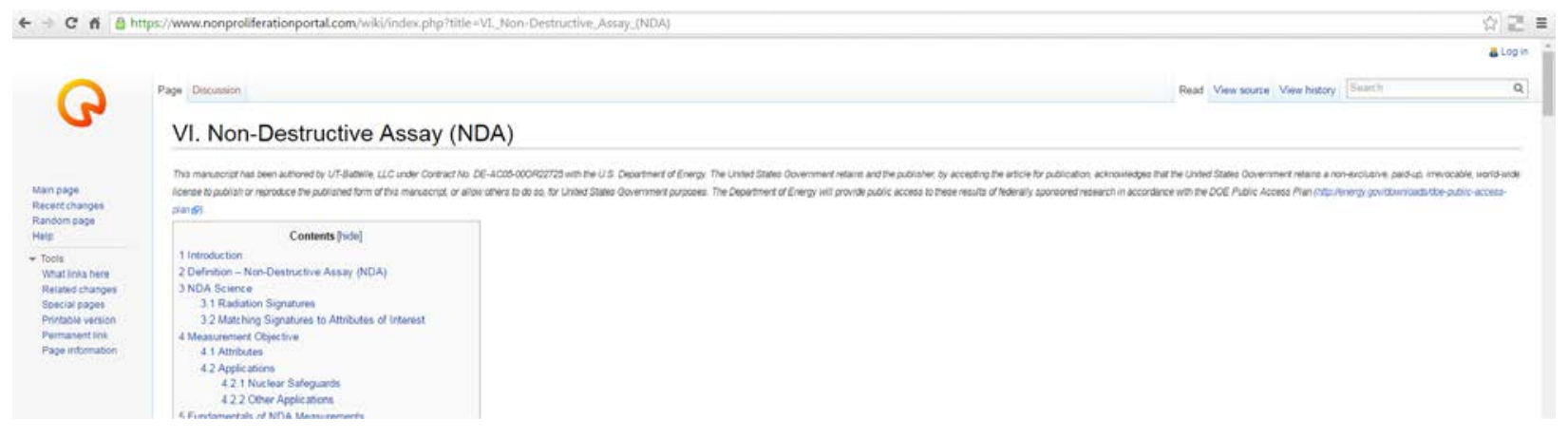

Figure 203. NDA Topic on NonproliferationPortal.com. 


\section{STATEMENTS BY THOSE BENEFITING FROM OINS SUPPORTED HCD ACTIVTIES}

Below is a sample of the feedback ORNL receives throughout the year, attesting to the value and benefits of the OINS HCD program.

\section{OINS Post Grad Experience by Hannah Hale-Salvo (University of Tennessee, Knoxville)}

I get to work with people from all over the world and know that I am having a direct impact on strengthening safeguards and security of nuclear materials in their countries.

\section{OINS Nonproliferation Workshop by Major Anthony Clark (West Point)}

This was an excellent educational experience. It provided the cadets excellent in-depth knowledge of the challenges faced in nonproliferation enforcement as well as expanded the students understanding of radiation detection. The students gained hands-on experience with advanced detection technologies as well as special nuclear material. This course was conducted in an extremely professional manner and was tailored to the particular knowledge base and interest of our audience. This workshop should be extended to all first class cadets enrolled in NE452 and should be modified to best suit that particular audience.

\section{OINS Graduate Student Intern Experience by Joseph Cope (NCSU)}

Working in the Nuclear Security Modeling group under Vince Jodoin allowed me to test the new Airborne Planning Tool among other tasks on the Ground Based Collection of Volatile Samples project. Commercial off-the-shelf air sampling technologies were investigated along with EPA's RadNet air samplers and the CTBTO's International Monitoring system for ground based volatile sample collection missions

\section{OINS Nonproliferation Workshop Student Josh Barnes (UNC-Chapel Hill)}

As a student of Peace, War, and Defense at the University of North Carolina, Chapel Hill, this trip was a marvelous companion to my course in Nuclear Security in the $21^{\text {st }}$ century. I am extremely grateful for the generous funding that allowing for this OINS Nonproliferation workshop to be possible. It was fascinating to bridge the policies we learned in class to the practical applications of what was being done every day to carry out those policies. Prior to this trip, I had been aware of the many people (and agencies) who actively preserve peace through nonproliferation and it was an absolute pleasure to listen to the people who do it every day. The hands-on demonstrations and presentations are something that cannot be replicated in the classroom, no matter how wonderful simulations and guest speakers are. This was a one-of-a-kind trip and was the highlight of my semester. 


\section{BIBLIOGRAPHY}

1. NNSA Office of Nonproliferation and International Security, International Safeguards: Challenges and Opportunities for the 21st Century, Executive Summary, http://nnsa.energy.gov/sites/default/files/nnsa/inlinefiles/NGSI_Report.pdf, October 2007.

2. NNSA Program Plan, November 2008.

3. Oak Ridge National Laboratory: Next-Generation Safeguards Initiative, ORNL/TM-2014/8, UT-Battelle LLC, Oak Ridge National Laboratory, 2014.

4. Oak Ridge National Laboratory: Next-Generation Safeguards Initiative, ORNL/TM-2012/539, UT-Battelle LLC, Oak Ridge National Laboratory, 2012.

5. Oak Ridge National Laboratory: Next-Generation Safeguards Initiative, ORNL/TM-2011/402, UT-Battelle LLC, Oak Ridge National Laboratory, 2011, http://info.ornl.gov/sites/publications/Files/Pub32787.pdf.

6. Nuclear Engineering Science Laboratory Synthesis, http://www.ornl.gov/sci/nsed/outreach/internship_nesls.shtml. 